\begin{tabular}{|c|c|}
\hline Title & $\begin{array}{l}\text { Enhanced levels of atmospheric low-molecular weight monocarboxylic acids in gas and particulates over Mt. Tai, North } \\
\text { China, during field burning of agricultural wastes }\end{array}$ \\
\hline Author(s) & Mochizuki, Tomoki; Kawamura, Kimitaka; Nakarnura, Shinnosuke; Kanaya, Y ugo; Wang, Zifa \\
\hline Citation & $\begin{array}{l}\text { A tmospheric environment, 171, 237-247 } \\
\text { https://doi.org/10.1016/.atmosenv.2017.10.026 }\end{array}$ \\
\hline Issue Date & $2017-12$ \\
\hline Doc URL & http:/hdl.handle.net/2115/75817 \\
\hline Rights & $\begin{array}{l}\text { O2017. This manuscript version is made available under the CC-BY-NC-ND } 4.0 \text { license } \\
\text { https:/creativecommons.org/icenses/by-nc-nd/4.0/ }\end{array}$ \\
\hline Rights(URL) & https://creativecommons.org/icenses/by-nc-nd/4.0/ \\
\hline Type & article (author version) \\
\hline File Information & Mochizuki et al. A tmos. Environ. 2017.pdf \\
\hline
\end{tabular}

Instructions for use 
1 Enhanced levels of atmospheric low-molecular weight monocarboxylic acids in gas and

4 Tomoki Mochizuki $^{1,2}$, Kimitaka Kawamura ${ }^{1,3^{*}}$, Shinnosuke Nakamura ${ }^{1,4}$, Yugo Kanaya ${ }^{5}$, and $5 \quad$ Zifa Wang ${ }^{6}$

6

7

particulates over Mt. Tai, North China, during field burning of agricultural wastes

${ }^{1}$ Institute of Low Temperature Science, Hokkaido University, Sapporo, Japan

${ }^{2}$ Now at School of Food and Nutritional Sciences, University of Shizuoka, Shizuoka, Japan

${ }^{3}$ Now at Chubu Institute for Advanced Studies, Chubu University, Kasugai, Japan

${ }^{4}$ Graduate School of Environmental Science, Hokkaido University, Sapporo, Japan

${ }^{5}$ Research Institute for Global Change, Japan Agency for Marine-Earth Science and Technology, Yokohama, Japan

${ }^{6}$ LAPC, Institute of Atmospheric Physics, Chinese Academy of Sciences, Beijing, China

\section{*Correspondence: kkawamura@isc.chubu.ac.jp}

Published in Atmospheric Environment

\section{Highlights:}

We determined gaseous and particulate $\mathrm{C}_{1}-\mathrm{C}_{10}$ monocarboxylic acids over Mt. Tai.

Formic $\left(\mathrm{C}_{1}\right)$ and acetic $\left(\mathrm{C}_{2}\right)$ acids were dominant followed by lactic acid.

High concentrations of $\mathrm{C}_{1}$ and $\mathrm{C}_{2}$ were observed during field burning of wheat straw.

High particle-phase fractions of $\mathrm{C}_{1}(0.50)$ and $\mathrm{C}_{2}(0.31)$ were observed.

Field burning of agricultural wastes is an important source of monocarboxylic acids.

Keywords: Acetic acid, Formic acid, Lactic acid, Gas/particle partitioning, Wheat straw burning, North East China 


\section{Abstract}

To understand the source and atmospheric behaviour of low molecular weight monocarboxylic acids (monoacids), gaseous $(\mathrm{G})$ and particulate $(\mathrm{P})$ organic acids were collected at the summit of Mt. Tai in the North China Plain (NCP) during field burning of agricultural waste (wheat straw). Particulate organic acids were collected with neutral quartz filter whereas gaseous organic acids were collected with $\mathrm{KOH}$-impregnated quartz filter. Normal $\left(\mathrm{C}_{1}-\mathrm{C}_{10}\right)$, branched $\left(\mathrm{iC}_{4}-\mathrm{iC}_{6}\right)$, hydroxy (lactic and glycolic), and aromatic (benzoic) monoacids were determined with a capillary gas chromatography employing p-bromophenacyl esters. We found acetic acid as the most abundant gas-phase species whereas formic acid is the dominant particle-phase species. Concentrations of formic (G/P $\left.1570 / 1410 \mathrm{ng} \mathrm{m}^{-3}\right)$ and acetic $\left(3960 / 1120 \mathrm{ng} \mathrm{m}^{-3}\right)$ acids significantly increased during the enhanced field burning of agricultural wastes. Concentrations of formic and acetic acids in daytime were found to increase in both $\mathrm{G}$ and $\mathrm{P}$ phases with those of $\mathrm{K}^{+}$, a field-burning tracer $(\mathrm{r}=0.32-0.64)$. Primary emission and secondary formation of acetic acid is linked with field burning of agricultural wastes. In addition, we found that particle-phase fractions $\left(F_{\mathrm{p}}\right.$ $=P /(G+P))$ of formic $(0.50)$ and acetic $(0.31)$ acids are significantly high, indicating that semi-volatile organic acids largely exist as particles. Field burning of agricultural wastes may play an important role in the formation of particulate monoacids in the NCP. High levels (917 $\mathrm{ng} \mathrm{m}^{-3}$ ) of particle-phase lactic acid, which is characteristic of microorganisms, suggest that microbial activity associated with terrestrial ecosystem significantly contributes to the formation of organic aerosols. 


\section{Introduction}

Low molecular weight (LMW) monocarboxylic acids (monoacids) are known to exist in the atmosphere as gases, aerosols, cloud, fog, and snow (Kawamura et al., 1985; Chebbi and Carlier, 1996; Kawamura et al., 2012). Formic and acetic acids are dominant organic species in the atmosphere. Concentrations of formic and acetic acids in gas phase are higher than those in particle phase (e.g., Andreae et al., 1988, Liu et al., 2012) due to their high vapour pressures. Global gaseous formic acid emission is estimated to be $100-120 \mathrm{Tg}$ year $^{-1}$ (Stavrakou et al., 2011), where formic acid comprises about $10 \%$ of the total emissions of non-methane volatile organic compounds. However, there is a significant missing source of organic acids. In particular, there is a limitation on our knowledge on how LMW monoacids exist in particles and what parameters control the gas/particle portioning of those organic acids.

Particulate formic and acetic acids are water-soluble and thus play an important role in the balance of radiative forcing acting as cloud condensation nuclei (CCN) (Yu, 2000). Gaseous formic and acetic acids are adsorbed on the existing alkaline particles. Möhler et al. (2008) reported that ice nuclei (IN) efficiency of mineral dust particles is decreased by the adsorptive uptake of organics on the particle surface. However, effects of organics on CCN and IN largely depend on their chemical composition or polarity. The organic aerosols that are enriched with organic acids contribute to the formation of $\mathrm{CCN}$ and $\mathrm{IN}$ and thus precipitation process, affecting the global water cycle and climate changes. On the other hand, high abundances of LMW organic acids in the atmosphere can adversely affect air quality and human health and also increase the acidity of rainwater (Keene et al., 1983, 1989; Kawamura et al., 1996).

Previous studies have shown that LMW monoacids are derived from both primary and secondary sources. LMW monoacids are directly emitted from fossil fuel combustion (Kawamura et al., 2000), vegetation (Kesselmeier and Staudt, 1999), soils (Asensio et al., 
2008), and ocean microorganisms (Miyazaki et al., 2014). The secondary sources include photooxidation of biogenic and anthropogenic organic compounds (Kawamura et al., 2000; Lim et al., 2005; Paulot et al., 2011; Brégonzio-Rozier et al., 2015). In addition, biomass burning is an important source of formic and acetic acids in gas and aerosol phases (Andreae et al., 1988; Kesselmeier and Staudt, 1999). However, gas/particle partitioning of formic and acetic acids emitted from biomass burning has rarely been studied. Further, there is no study on gas/particle partitioning of normal $\left(\mathrm{C}_{3}-\mathrm{C}_{10}\right)$, branched chain $\left(\mathrm{iC}_{4}-\mathrm{iC}_{6}\right)$, and hydroxy (lactic acid) monoacids in the atmosphere.

East China is one of the most polluted regions in the world, where many mega cities such as Beijing and Shanghai are located. Our previous studies reported that concentrations of levoglucosan, a biomass burning tracer (Fu et al., 2008), dicarboxylic acids (Kawamura et al., 2013a), and $\alpha$-dicarbonyls (Kawamura et al., 2013b) significantly increased over the summit of Mt. Tai in the North China Plain (NCP) during the field burning of agricultural wastes. The inflow of those polluted air masses may adversely affect the air quality even in urban areas such as Beijing and outflow regions in East Asia and the western North Pacific.

In this study, we collected gas and particle samples at the summit of Mt. Tai during June 2006 to better understand the distributions of LMW monoacids during the field burning of agricultural residue. We utilized two-stage filter pack sampling technique (see the experimental section) followed by derivatization to $p$-bromophenacyl esters to determine gas and particulate monoacids simultaneously (Kawamura et al., 1985). Further, utilization of a capillary gas chromatograph (GC) provides very high resolution and sensitivity and hence relatively minor species such as propionic acid $\left(\mathrm{C}_{3}\right)$ and $\mathrm{C}_{4}-\mathrm{C}_{10}$ monoacids, which are not detectable by ion chromatography, can be detected by GC method (Kawamura et al., 1985). By modifying the method of Kawamura et al. (1985), we determined hydroxy (lactic and glycolic) acids together with normal $\left(\mathrm{C}_{1}-\mathrm{C}_{10}\right)$, branched $\left(\mathrm{iC}_{4}-\mathrm{iC}_{6}\right)$, and aromatic (benzoic) monoacids in both gas and aerosol phases. Although this technique has been used for air and 
100 rainwater samples from Los Angeles (Kawamura et al., 2000, 2001), it application has not

101 been conducted to air samples from Asian regions. Here we report, for the first time, gaseous and particulate LMW monoacids that are most likely derived from the field burning of agricultural wastes. We also discuss gas/particle partitioning of monoacids during the field burning of wheat straws in the NCP and potential contribution of microbial activity to organic aerosols. sampling period.

\section{Experimental}

Sampling of gaseous and particulate LMW monoacids was conducted at the top of Mt. Tai $\left(36.26^{\circ} \mathrm{N}, 117.11^{\circ} \mathrm{E}\right.$, elevation: $1534 \mathrm{~m}$ above sea level) located in Shandong Province, North China (Figure 1) as part of the Mount Tai Experiment 2006 campaign (MXT2006) (Kanaya et al., 2013). Sample collections were performed every 3 hours (00:00-03:00, 03:00-06:00, 06:00-09:00, 09:00-12:00, 12:00-15:00, 15:00-18:00, 18:00-21:00, 21:0024:00 LT) on June $2-5$ and 23-25, 2006. Totally 36 sets of samples (72 filters) were collected for both particulate and gaseous LMW monoacids employing neutral and $\mathrm{KOH}$-impregnated quartz fibre filters, respectively. Here, we compare the atmospheric abundances of gaseous and particulate organic acids between more and less field-burning periods. The weather conditions were sunny or cloudy during the campaign. Meteorological parameters such as ambient temperature, relative humidity, wind direction, and wind speed were measured at the Mt. Tai Observatory and reported previously (Kanaya et al., 2013; Kawamura et al., 2013a). The height of planetary boundary layer (PBL) are provided by the Global Data Assimilation System (GDAS1) (Air Resources Laboratory, NOAA). Average PBL in daytime and nighttime were about $2200 \mathrm{~m}$ and about $600 \mathrm{~m}$, respectively. Daytime samples were collected within the PBL and nighttime samples were collected in the free troposphere during the

To collect ambient monoacids in gas and particle phases, a low-volume air sampler 
equipped with the two-stage filter packs (URG-2000-30FG) were set in a series at the balcony of two-story building of the observatory (height: $10 \mathrm{~m}$ ) near the summit of Mt. Tai. Total particulate monoacids were collected on precombusted $\left(450{ }^{\circ} \mathrm{C}, 6 \mathrm{~h}\right)$ neutral quartz-fiber filter (47 mm diameter) (first stage) whereas gaseous monoacids were collected on the quartz-fiber filter impregnated with potassium hydroxide (KOH) (second stage) at an airflow rate of $8.4 \mathrm{~L} \mathrm{~min}^{-1}$. The $\mathrm{KOH}$ impregnated filters were prepared by rinsing the precombusted quartz filter in a $0.2 \mathrm{M} \mathrm{KOH}$ solution and then dried in an oven at $80{ }^{\circ} \mathrm{C}$. The details of filter preparation and analytical method were described previously (Kawamura et al., 1985). Both the neutral and alkaline filters were individually placed in clean glass vials $(50 \mathrm{ml})$ with a Teflon-lined screw cap to avoid a gas exchange with ambient air before and after the sampling. After the sampling, filter samples were transported to the lab in Sapporo and stored in a freezer room at $-20^{\circ} \mathrm{C}$ prior to analysis.

An aliquot of filter $\left(4.3 \mathrm{~cm}^{2}\right)$ was extracted with organic free ultrapure water $(5 \mathrm{ml} \times$ 3, > 18.2 $\mathrm{M} \Omega \mathrm{cm}$ ) under ultrasonication. To remove particles and filter debris, the extracts were passed through a Pasteur pipette packed with quartz wool. To avoid the evaporative loss of volatile monoacids during analytical procedures, the $\mathrm{pH}$ of water extracts was adjusted to 8.5-9.0 with $0.05 \mathrm{M} \mathrm{KOH}$ solution to form organic acid salts (e.g., $\mathrm{CH}_{3} \mathrm{COO}^{-} \mathrm{K}^{+}$). The organic acid salts were concentrated using a rotary evaporator under vacuum at $50{ }^{\circ} \mathrm{C}$. To make all the organic acid salts to $\mathrm{RCOO}^{-} \mathrm{K}^{+}$form, the concentrates were passed through a cation exchange resin (DOWEX 50W-X4, 100-200 mesh, $\mathrm{K}^{+}$form) packed in a Pasteur pipette. The eluents were finally checked for $\mathrm{pH}=8.5-9.0$ and then concentrated using a rotary evaporator under vacuum. The dried $\mathrm{RCOO}^{-} \mathrm{K}^{+}$salts were derivatized in acetonitrile $(4 \mathrm{ml})$ with $\alpha, p$-dibromoacetophenone $(0.1 \quad \mathrm{M}, \quad 50 \mu \mathrm{l})$ as a derivatization reagent and dicyclohexyl-18-crown-6 $(0.01 \mathrm{M}, 50 \mu \mathrm{l})$ as a catalyst at $80{ }^{\circ} \mathrm{C}$ for 2 hours (Kawamura and Kaplan, 1984).

The derivatives ( $p$-bromophenacyl esters) of monoacids including normal $\left(\mathrm{C}_{1}-\mathrm{C}_{10}\right)$, 
152 branched $\left(\mathrm{iC}_{4}-\mathrm{iC}_{6}\right)$, and aromatic (benzoic acid) structures were measured using a capillary

153 gas chromatograph (GC) (HP GC6890, Hewlett-Packard, USA) equipped with a flame

154

155

156

157

158

159

160

161

162

163

164

165

166

167 ionization detector. The GC peaks were identified using a GC-mass spectrometer (GC/MS) (Agilent GC7890A and 5975C MSD, Agilent, USA). The mass spectra of $p$-bromophenacyl esters of monoacids are presented in Kawamura and Kaplan (1984).

The $\mathrm{OH}$ functional groups in $p$-bromophenacyl esters of organic acids were further reacted with N,O-bis-(trimethylsilyl)trifluoroacetamide (BSTFA) with 1\% trimethylsilyl chloride and $10 \mu \mathrm{l}$ of pyridine at $70{ }^{\circ} \mathrm{C}$ for 3 hours to derive trimethylsilyl (TMS) ethers of p-bromophenacyl esters. The derived TMS ethers were determined with a capillary GC and GC/MS. We determined hydroxymonocarboxylic acids including lactic and glycolic acids. Details of the methods have been described in Kawamura et al. (2012).

A mixture of organic acids was prepared in our laboratory from the authentic standards: $\mathrm{C}_{1}-\mathrm{C}_{7}$ and $\mathrm{iC}_{4}-\mathrm{iC}_{6}(10 \mathrm{mM}$ in water, assay $98 \%$, Sigma-Aldrich), lactic acid (assay $>85 \%$, Wako), glycolic acid (assay 97\%, Wako), and benzoic acid (assay 99\%, Tokyo Chemical Industry Co.). To check the recoveries of organic acids during the analytical procedures, authentic monoacid standards $\left(\mathrm{C}_{1}-\mathrm{C}_{10}\right.$, benzoic, lactic, and glycolic acids $)$ were spiked to $\mathrm{KOH}$-impregnated quartz filters and the filters were analysed as a real sample. The results showed that the recoveries were more than $80 \%$. Analytical errors using authentic standards were within $12 \%$. Detection limits of organic acids in our analytical method were ca. $0.02 \mathrm{ng} \mathrm{m}^{-3}$. Filed blank filters were prepared by the same sampling procedures without pumping air. We found that blank levels of monoacids were less than $\sim 5 \%$ of those of ambient samples in both gaseous and particulate phases. In addition, we analyzed laboratory blanks for monoacids, in which the same analytical protocols were used. The blank levels were less than $\sim 5 \%$ of those of ambient samples. The concentrations reported here are corrected against the field and laboratory blanks, but not corrected for the recoveries. 
during sampling and be collected on the second filter (KOH-impregnated). Thus, particulate organic acids could be underestimated and gaseous organic acids could be overestimated. However, we believe that evaporative loss should be minimal based on the experimental results from Los Angeles (Kawamura et al., 1985, 2000). Samplings of total suspended particles over the Mt. Tai and Los Angeles were conducted by the same sampling system.

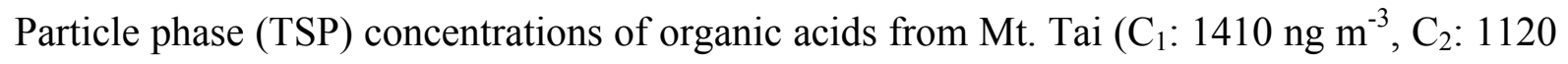
$\mathrm{ng} \mathrm{\textrm {m } ^ { - 3 }}$ ) are higher than those $\left(\mathrm{C}_{1}: 163 \mathrm{ng} \mathrm{m}^{-3}, \mathrm{C}_{2}: 120 \mathrm{ng} \mathrm{m}^{-3}\right)$ from Los Angeles (Kawamura et al., 2000). Particulate organic acids collected on a neutral quartz filter (first stage) have been reported to be less than $\sim 17 \%$ of total (gas + particulate) organic acids in Los Angeles (Kawamura et al., 1985). We found that particulate monoacids are sometimes more abundant than gaseous monoacids in this study, which may be in part associated with lower ambient air temperature on the top of Mt. Tai $\left(12-20^{\circ} \mathrm{C}\right.$, average $\left.16^{\circ} \mathrm{C}\right)$ than in Los Angeles (summer) and other parameters as discussed later.

Keene et al. (1989) showed that alkaline $(\mathrm{NaOH})$ impregnated filter with glycerol $\left(\mathrm{C}_{3} \mathrm{H}_{8} \mathrm{O}_{3}\right)$ results in positive interferences of formic and acetic acids. Concentrations of formic and acetic acids in gas phase may be overestimated in the previous studies where glycerol was used because glycerol may be reacted with oxidants to result in formic and acetic acids. However, we did not use glycerol in this study. Gaseous monoacids may be subjected to atmospheric titration by alkaline dust particles $(\mathrm{Ca}, \mathrm{Na}, \mathrm{K}$ and $\mathrm{Mg}$ ) in the atmosphere. Organic acids in aerosols may exist in the form of salts such as RCOOK, RCOONa, and others. Vapor pressures of those salts are significantly lower than those of free monoacids. In this study, aerosol samples were collected to differentiate free organic acids and organic acid salts using $\mathrm{KOH}$-impregnated and neutral quartz filters, respectively. We calculated ion balance in the aerosols over Mt. Tai (Please see discussion section). Total cations are slightly higher than total anions. We think that absorption of gas phase organic acids in aerosol phase on the first filter is limited. 
For the measurements of inorganic ions (cations: $\mathrm{Na}^{+}, \mathrm{NH}_{4}{ }^{+}, \mathrm{K}^{+}, \mathrm{Mg}^{2+}$, and $\mathrm{Ca}^{2+}$ and 205 anions: $\mathrm{F}^{-}, \mathrm{MSA}^{-}, \mathrm{Cl}^{-}, \mathrm{NO}_{2}^{-}, \mathrm{NO}_{3}^{-}, \mathrm{Br}^{-}, \mathrm{PO}_{4}{ }^{3-}$, and $\left.\mathrm{SO}_{4}{ }^{2-}\right)$, ambient aerosols were collected 206 onto quartz-fiber filter $(20 \times 25 \mathrm{~cm})$ (Tissuquartz 2500QAT-UP, Pallflex, USA) using a 207 high-volume air sampler during the same sampling period. A portion of filter was extracted 208 with ultrapure water under ultrasonication. The water extracts were filtered through a 209 membrane disk filter $(0.22 \mu \mathrm{m}$, Millipore Millex-GV, Merck, USA) and then analyzed using an ion chromatograph (Model 761 compact IC, Metrohm, Switzerland) (Miyazaki et al., 2009). Anion analysis was conducted using a Shodex SI-90 4E column and a $1.8 \mathrm{mM}$ $\mathrm{Na}_{2} \mathrm{CO}_{3}+1.7 \mathrm{mM} \mathrm{NaHCO}$ solution as an eluent. Cation analysis was performed using a C2-150 column and a $4.0 \mathrm{mM}$ tartaric acid plus $1.0 \mathrm{mM}$ dipicolinic acid solution as an eluent.

214 The analytical errors in duplicate analyses of samples were within $4 \%$. Carbon monoxide (CO) concentration was continuously monitored with a non dispersive infrared gas analyzer (Model 48C, Thermo Scientific, USA). The CO data were obtained from Kanaya et al. (2009).

Seven-day backward and forward air mass trajectories were calculated over the summit of Mt. Tai at a level of $1500 \mathrm{~m}$ and $750 \mathrm{~m}$ a.s.l. using the Meteorological Data Explorer (METEX) from the National Institute for Environmental Studies, Tsukuba, Japan 221 (http://db.cger.nies.go.jp/metex/index.html). Meteorological data were obtained from the 222 National Centers for Environmental Prediction (NCEP) Reanalysis data. In addition, we have 223 checked weather conditions in Mt. Tai, Beijing, and Shanghai. Weather information were 224 obtained from the National Oceanic and Atmospheric Administration. Extreme weather 225 events did not occur during the period 28 May to 30 June 2006. Fire spot data sets were 226 downloaded from MODIS fire spot measurement data 227 (http://earthdata.nasa.gov/data/near-real-time-data/firms). 


\subsection{Characteristics of air mass and fire spots}

Figure 2 shows typical ten-day air mass back trajectories (1500 m a.s.1.) with fire spots. In the North China Plain (NCP), harvest season of wheat starts in late May and then agricultural wastes (wheat straw) are burned in the open field. The field burning was heavily observed from the satellite over the NCP from 2 to 4 June, especially, in the south of Mt. Tai. The field burning declined during 23-25 June with a shift of the hot spot areas to the north and northwest of the sampling site. The air masses at a levels of $1500 \mathrm{~m}$ and $750 \mathrm{~m}$ (Please see Figure A1) during 3-4 June have passed over the heavy fire spot regions. These days are strongly influenced by the agricultural waste burning. On the other hand, the air mass (1500 $\mathrm{m}$ and $750 \mathrm{~m}$ ) of 2 June was mainly originated from the Sea of Japan. The air masses at a level of $1500 \mathrm{~m}$ on 23 and 25 June were transported from the NCP and South China, respectively. Although the air masses at a level of $1500 \mathrm{~m}$ on 23 and 25 June were not consistent with those of $750 \mathrm{~m}$, the air masses of 2, 23 and 25 June were less affected by the field burning of agricultural wastes. In addition, concentrations of $\mathrm{K}^{+}$, a good tracer of field burning (Andreae, 1983), increased on 3-5 June and decreased on 23 and 25 June (Figure 3). These results are consistent with the spatial distributions of fire spots and air mass trajectories arriving over the sampling site. Hence, the air masses of 3-4 June were primarily delivered from the areas of the field burning of agricultural residue. In this study, the data were categorized into two periods: more field-burning (MFB) (3-5 June) and less field-burning (LFB) (2 and 23-25 June) influenced periods.

\subsection{Gaseous and particulate LMW monoacids}

We identified LMW monoacids; such as normal (formic: $\mathrm{C}_{1}$, acetic: $\mathrm{C}_{2}$, propionic: $\mathrm{C}_{3}$, butyric: $\mathrm{C}_{4}$, pentanoic: $\mathrm{C}_{5}$, hexanoic: $\mathrm{C}_{6}$, heptanoic: $\mathrm{C}_{7}$, octanoic: $\mathrm{C}_{8}$, nonanoic: $\mathrm{C}_{9}$, and decanoic: $\mathrm{C}_{10}$ ), branched chain (isobutyric: $\mathrm{iC}_{4}$, isopentanoic: $\mathrm{iC}_{5}$, and isohexanoic: $\mathrm{iC}_{6}$ ), hydroxy acids (lactic: Lac, and glycolic: Glyco), and aromatic (benzoic: Benz) acids in both 
gas and particle phases. Figure 4 shows average molecular compositions of detected LMW monoacids in the MFB and LFB periods. Acetic acid was the dominant species in gas phase in the MFB (61\%) and LFB (41\%) periods, followed by formic acid (MFB: 24\%, LFB: 29\%) and lactic acid (MFB: 5\%, LFB: 14\%). In particle phase, formic acid was the dominant species in the MFB (34\%) and LFB (31\%) periods, followed by acetic acid (MFB: 27\%, LFB: 27\%) and lactic acid (MFB: 22\%, LFB: 23\%). In addition, isopentanoic acid in particle phase was the fourth most abundant monoacid in the MFB (8\%) and LFB (7\%) periods. Nonanoic acid $\left(\mathrm{C}_{9}\right)$ is the fifth most abundant monoacid in both gas- and particle-phases, showing a peak in the range of $\mathrm{C}_{5}-\mathrm{C}_{10}$ monoacids during the MFB and LFB periods (Table 1). $\mathrm{C}_{9}$ is an oxidation product of oleic acid $\left(\mathrm{C}_{18: 1}\right)$ containing a double bond at C-9 position (Kawamura and Gagosian, 1987).

Figure 3 shows temporal variations in the concentrations of major LMW monoacids in gas and particle phases. The gaseous concentrations of acetic acid during the MFB period (3-5 June) are significantly higher than those during the LFB period (2 and 2325 June). Similarly, the gas-phase concentrations of formic acid are higher during the MFB period than the LFB period. The particle-phase concentrations of formic and acetic acids during the MFB period are slightly higher than those during the LFB period. We found that particle-phase formic and acetic acids were less abundant in the morning and nighttime hours but maximized around noontime or in the afternoon. Two peaks of isopentanoic $\left(\mathrm{iC}_{5}\right)$ and lactic (Lac) acids in particle-phase were observed at 6:00-9:00 on 3 June and 9:00-12:00 on 4 June when the field burning of agricultural wastes increased (Figure 2a). However, these acids did not show any diurnal trend in both gas and particle phases.

Concentrations of total monoacids in gas-phase ranged from 1530 to $12,100 \mathrm{ng} \mathrm{m}^{-3}$ whereas those in particle-phase ranged from 960 to $9680 \mathrm{ng} \mathrm{m}^{-3}$. Mean concentrations of total monocarboxylic acids in gas-phase were $6540 \mathrm{ng} \mathrm{m}^{-3}$ during the MFB and $3070 \mathrm{ng} \mathrm{m}^{-3}$ during the LFB period, whereas those in particle-phase were $4120 \mathrm{ng} \mathrm{m}^{-3}$ during the MFB 
282

283

284

285

286

and $2850 \mathrm{ng} \mathrm{m}^{-3}$ during the LFB period. Overall, gas-phase concentrations of total monoacids are higher than those of particle phase in both MFB and LFB periods. Table 1 summarises average concentrations of individual monoacids over Mt. Tai. In gas-phase, acetic acid was found as the dominant monoacid species (MFB: $3960 \mathrm{ng} \mathrm{m}^{-3}$, LFB: $1270 \mathrm{ng} \mathrm{m}^{-3}$ ) followed by formic acid (MFB: $1570 \mathrm{ng} \mathrm{m}^{-3}$, LFB: $890 \mathrm{ng} \mathrm{m}^{-3}$ ) and lactic acid (MFB: $319 \mathrm{ng} \mathrm{m}^{-3}$, LFB: $433 \mathrm{ng} \mathrm{m}^{-3}$ ). In particle-phase, formic acid is the dominant species (MFB: $1410 \mathrm{ng} \mathrm{m}^{-3}$, LFB: $883 \mathrm{ng} \mathrm{m}^{-3}$ ) followed by acetic acid (MFB: $1120 \mathrm{ng} \mathrm{m}^{-3}$, LFB: $763 \mathrm{ng} \mathrm{m}^{-3}$ ), and lactic acid (MFB: $917 \mathrm{ng} \mathrm{m}^{-3}$, LFB: $661 \mathrm{ng} \mathrm{m}^{-3}$ ). Mean concentrations of major monoacids in both gas and particle phases are greater during the MFB period than the LFB period, except for gaseous lactic acid and isopentanoic acid $\left(\mathrm{iC}_{5}\right)$.

The particle-phase fractions $\left(F_{\mathrm{p}}\right)$ of each organic acid were calculated as $F_{\mathrm{p}}=$ $P /(G+P)$, where $P$ is the particle-phase concentration and $G$ is the gas phase concentration. Figure 5 shows temporal variations in the $F_{\mathrm{p}}$ of major monoacids. $F_{\mathrm{p}}$ of acetic $\left(\mathrm{C}_{2}\right)$ and propionic $\left(\mathrm{C}_{3}\right)$ acids are slightly lower during the MFB period (3-5 June) than other period. The $F_{\mathrm{p}}$ for other LMW monocarboxylic acids over Mt. Tai did not show any clear temporal or diurnal variations. Table 1 also summarizes mean $F_{\mathrm{p}}$ for individual monoacids during the MFB and LFB periods. $F_{\mathrm{p}}$ of individual monoacids during the MFB and LFB periods ranged from $0.19\left(\mathrm{C}_{3}\right)$ to $0.78\left(\mathrm{C}_{6}\right)$ and $0.27\left(\mathrm{C}_{4}\right)$ to $0.93\left(\mathrm{iC}_{6}\right)$, respectively. $F_{\mathrm{p}}$ of acetic acid was 0.24 during the MFB and 0.38 during the LFB, whereas $F_{\mathrm{p}}$ of formic acid was 0.47 during the MFB and 0.52 during the LFB. $F_{\mathrm{p}}$ of acetic and formic acids during the MFB period are significantly lower than those during the LFB period. On the other hand, $F_{\mathrm{p}}$ of hydroxymonoacids, e.g., lactic acid, and branched chain monoacids, e.g., isopentanoic acid, are significantly high $(0.62-0.92)$, however, there is no systematic trend of the $F_{\mathrm{p}}$ values between the MFB and LFB periods (Table 1).

\section{Discussion}




\subsection{Impact of field burning on the concentrations of formic and acetic acids}

To evaluate the effect of biomass burning of agricultural wastes on gaseous and particulate formic and acetic acids, we plotted formic and acetic acids against levoglucosan (a good tracer of biomass burning) (Simoneit, 2002) (Figure 6 and Figure A3). Particulate formic and acetic acids in daytime show a weak correlation with levoglucosan during the $\operatorname{MFB}\left(\mathrm{C}_{1}: \mathrm{r}=0.29, \mathrm{C}_{2}: \mathrm{r}=0.28\right)$ and $\operatorname{LFB}\left(\mathrm{C}_{1}: \mathrm{r}=0.28, \mathrm{C}_{2}: \mathrm{r}=0.24\right)$ periods. Gaseous formic and acetic acids in daytime did not show a positive correlation with levoglucosan $(r=-0.62-$ 0.35). In addition, $\mathrm{K}^{+}$is emitted from field burning and agricultural activities, which is an open field burning tracer. We plotted formic and acetic acids against $\mathrm{K}^{+}$(Figure 7 and Figure A4). Particulate formic and acetic acids in daytime showed a positive correlation with $\mathrm{K}^{+}$ during the MFB $\left(\mathrm{C}_{1}: \mathrm{r}=0.59, \mathrm{C}_{2}: \mathrm{r}=0.64\right)$ and $\mathrm{LFB}\left(\mathrm{C}_{1}: \mathrm{r}=0.44, \mathrm{C}_{2}: \mathrm{r}=0.63\right)$ periods, whereas particulate formic and acetic acids in nighttime did not show any correlations with $\mathrm{K}^{+}(\mathrm{r}=-0.29-0.04)$

We found that concentrations of gaseous acetic acid in daytime increased with $\mathrm{K}^{+}$ during the MFB $(r=0.63)$ and LFB $(r=0.63)$ periods. Gaseous acetic acid in nighttime showed a positive correlation with $\mathrm{K}^{+}(\mathrm{MFB}: \mathrm{r}=0.54$, LFB: $\mathrm{r}=0.39)$. However, formic acid in both gas and particle phases in nighttime showed no correlation with $\mathrm{K}^{+}$during the MFB and LFB periods $(r=-0.29-0.38)$. We found that particulate formic and acetic acids and gaseous acetic acid showed good correlations with $\mathrm{K}^{+}$and no correlations with levoglucosan. Our results suggest that particulate formic and acetic acids and gaseous acetic acid are influenced by the open filed burning in the NCP. Although the sampling was conducted in the MFB and LFB periods at this study, the obtained data must be interpreted with caution because of a limited number of samples.

During the sampling periods, concentrations of formic and acetic acids and $\mathrm{K}^{+}$in daytime were higher than those in nighttime. Because the top of Mt. Tai in daytime is below the PBL, organic acids as well as other gaseous and aerosols are uplifted to Mt. Tai from the 
lowland agricultural areas in the NCP where field burning of wheat straws is widely operated.

Table 2 compares the concentrations of formic and acetic acids in gas- and particle-phases from multiple sites in the world. Particle-phase concentrations of formic (1410 $\left.\mathrm{ng} \mathrm{m}^{-3}\right)$ and acetic $\left(1120 \mathrm{ng} \mathrm{m}^{-3}\right)$ acids over Mt. Tai during the MFB period are significantly higher than those reported in Los Angeles (Kawamura et al., 2000), megacities of China such as Beijing (Wang et al., 2005) and Shanghai (Wang et al., 2006), Amazon forest (Andreae et al., 1988) and Taiwan forest (Tsai and Kuo, 2013), and Alaska (Li and Winchester, 1989). On the other hand, the gaseous levels of formic $\left(1570 \mathrm{ng} \mathrm{m}^{-3}\right)$ and acetic (3960 $\mathrm{ng} \mathrm{m}^{-3}$ ) acids over Mt. Tai during the MFB period are lower than those reported in tropical forests from Amazon (Andreae et al., 1988), biomass burning plumes from the Yangtze River Delta region, China (Kudo et al., 2014), urban air from Pasadena (Yuan et al., 2015), and oil and gas fields from Utah (Yuan et al., 2015). The concentrations of formic and acetic acids at Mt. Tai are 2-5 times higher than those reported from Los Angeles (Kawamura et al., 2000), Greenland (Dibb and Arsenault, 2002), and the French Alps (Preunkert et al., 2007), and 1-2 orders of magnitude higher than those reported from the Pacific Ocean (Miyazaki et al., 2014) and Antarctica (Legrand et al., 2012). These comparisons demonstrate that concentrations of formic and acetic acids in gas and particle phases during field burning of wheat straw are relatively high compared with those from other sites.

Carbon monoxide (CO) is originated from biomass burning (Wang et al., 2002) and anthropogenic sources such as fossil fuel combustion. Average concentrations of $\mathrm{CO}$ in the MFB and LFB periods were 553 ppb and 467 ppb, respectively (Kanaya et al., 2009), which levels were very high and the air over Mt. Tai during the sampling periods was highly polluted. Mean concentrations of total monoacids in both gas and particle phases are greater during the MFB period (P: $4130 \mathrm{ng} \mathrm{m}^{-3}$, G: $6540 \mathrm{ng} \mathrm{m}^{-3}$ ) than the LFB period (P: $3070 \mathrm{ng} \mathrm{m}^{-3}$, $\mathrm{G}: 2860 \mathrm{ng} \mathrm{m}^{-3}$ ). Field burning of agricultural wastes is an important source of monoacids in 
the atmosphere over Mt. Tai. In addition, Figure A2 shows seven-day air mass forward trajectories during the MFB period. The dominant air mass flow at a levels of $1500 \mathrm{~m}$ and $750 \mathrm{~m}$ was northeasterly and easterly, indicating outflow of air masses to East Asia and the western North Pacific. We suggest that high abundances of monoacids in the particle phases not only degrade the air quality in East Asia but also largely contribute to enhance the hygroscopic properties of ambient aerosols because they are highly water-soluble. A possible formation of gaseous and particulate acetic acid will be discussed in section 4.3.

\subsection{Gas/particle partitioning of formic, acetic, and lactic acids}

Generally, $F_{\mathrm{p}}$ increases with an increase of carbon numbers of monoacids (Yatavelli et al., 2014). However, the $F_{\mathrm{p}}$ values of formic $(0.47-0.52)$ and acetic $(0.24-0.38)$ acids at the top of Mt. Tai are larger than the values expected from the high vapour pressures of formic $\left(V_{\mathrm{p}}=5.6 \times 10^{-2} \mathrm{~atm}\right)$ and acetic $\left(V_{\mathrm{p}}=2.1 \times 10^{-2} \mathrm{~atm}\right)$ acids. In addition, $F_{\mathrm{p}}$ values of $\mathrm{C}_{1}$ and $\mathrm{C}_{2}$ over Mt. Tai are significantly larger than those reported from the Pacific Ocean $\left(\mathrm{C}_{1}: F_{\mathrm{p}}=0.04\right.$, $\left.\mathrm{C}_{2}: F_{\mathrm{p}}=0.06\right)\left(\right.$ Miyazaki et al., 2014) and urban Los Angeles $\left(\mathrm{C}_{1}: F_{\mathrm{p}}=0.16, \mathrm{C}_{2}: F_{\mathrm{p}}=0.06\right)$ (Kawamura et al., 2000), in which the same sampling and analytical protocols were used. On the other hand, the $F_{\mathrm{p}}$ of lactic acid $(0.61-0.69)$ over Mt. Tai is slightly lower than that reported from the Pacific Ocean (0.76 - 0.82) (Miyazaki et al., 2014).

Khan et al. (1995) reported that ambient temperature and relative humidity $(\mathrm{RH})$ are important factors to determine the gas-particle partitioning of organic acids. Gas-particle partitioning of organic acids depend on temperature (related to Henry's law) and RH (related to aerosol liquid water content indicator). In this study, diurnal variations of temperature and RH were observed. However, there is no consistent relationship between $F_{\mathrm{p}}$ of organic acids and temperature or $\mathrm{RH}$. The ambient temperature and $\mathrm{RH}$ did not affect aerosol surface characteristics over Mt. Tai.

As a potential reason of higher $F_{\mathrm{p}}$ values for organic acids, chemical states of those 
acids in ambient aerosols should be considered. For example, ammonia reacts with gaseous acidic species (e.g., oxalic acid) (Paciga et al., 2014). Gas phase acetic acid can be adsorbed on calcite $\left(\mathrm{CaCO}_{3}\right)$ that is a major component of mineral dust (Alexander et al., 2015). Because the vapour pressures of organic salts are lower than those of free organic acids, gas to particle conversion of organic acids may be an important factor to control their gas/particle partitioning. However, the $F_{\mathrm{p}}$ of formic and acetic acids did not show correlation with alkaline species such as $\mathrm{Na}^{+}, \mathrm{K}^{+}, \mathrm{Ca}^{2+}, \mathrm{Mg}^{2+}$, and $\mathrm{NH}_{4}{ }^{+}$(MFB: $\mathrm{r}<-0.12$, LFB: $\left.\mathrm{r}<0.24\right)$. We calculated total cation equivalents $\left(\mathrm{Na}^{+}, \mathrm{NH}_{4}^{+}, \mathrm{K}^{+}, \mathrm{Mg}^{2+}\right.$, and $\left.\mathrm{Ca}^{2+}\right)$ and total anion equivalents $\left(\mathrm{F}^{-}, \mathrm{MSA}^{-}, \mathrm{Cl}^{-}, \mathrm{NO}_{2}^{-}, \mathrm{NO}_{3}^{-}, \mathrm{Br}^{-}, \mathrm{PO}_{4}{ }^{3-}\right.$, and $\left.\mathrm{SO}_{4}{ }^{2-}\right)$ including normal $\left(\mathrm{C}_{1}-\mathrm{C}_{10}\right)$, branched chain $\left(\mathrm{iC}_{4}-\mathrm{iC}_{6}\right.$ ), aromatic (benzoic), and hydroxyl (lactic and glycolic) monoacids, although $\mathrm{CO}_{3}{ }^{-}$and $\mathrm{HCO}_{3}{ }^{-}$, as well as unidentified organic anions, were not considered. The slope of more than unity (1.21) indicates that excess cations exist in the aerosols over Mt. Tai. We calculated total cation equivalents minus total anion equivalents (cations - anions) in the particles from Mt. Tai. $F_{\mathrm{p}}$ of formic $\left(\mathrm{C}_{1}\right)$ and acetic $\left(\mathrm{C}_{2}\right)$ acids did not show a positive correlation with cation - anions $\left(\mathrm{C}_{1}: \mathrm{r}=-0.36, \mathrm{C}_{2}: \mathrm{r}=-0.28\right)$. Gas to particle conversion of formic and acetic acids over Mt. Tai was not controlled by the above-mentioned excess alkaline species.

Barsanti et al. [2009] reported that amines can more easily form organic acid salts compared to ammonia. Unfortunately, we did not measure amines in this study. Amines that are derived from vehicle exhaust and animal husbandry (e.g., Cape et al., 2011) and from biomass burning (Ge et al., 2011) could act as a counterpart for free organic acids and those amine-organic acid reactions may contribute to a new particle formation and condensation growth of particles, enhancing the $F_{\mathrm{p}}$ values in the NCP. We suggest that gas/particle partitioning of formic and acetic acids may be influenced by unidentified factors during atmospheric transport over Mt. Tai, which need further study to be clarified in the future. 


\subsection{Primary and secondary sources of formic and acetic acid}

Formic acid $\left(C_{1}\right)$ is largely derived from secondary sources (Khwaja et al., 1995, Pommier et al., 2016), whereas acetic acid $\left(C_{2}\right)$ is largely emitted from primary sources (Kawamura et al., 1985, 2000). The ratio of $\mathrm{C}_{1} / \mathrm{C}_{2}$ in particle phase is an indicator for primary or secondary source of organic acid aerosol. Talbot et al. (1988) reported that high ratio of $\mathrm{C}_{1} / \mathrm{C}_{2}(>1)$ means the dominance of secondary sources, whereas low ratio $(<1)$ means the dominance of primary sources. In this study, average ratio of $C_{1} / C_{2}$ in daytime in the MFB and LFB periods was 1.3 and 1.2 , respectively. $\mathrm{C}_{1} / \mathrm{C}_{2}$ ratios of Mt. Tai are higher than those reported from urban in China (Shanghai: 0.5) (Wang et al., 2006), tropical rain forest (1.0) (Andreae et al., 1988), and Ocean (0.3) (Miyazaki et al., 2014) and are comparable to those reported from urban Los Angeles (1.4) (Kawamura et al., 2000) and China (Beijing: 1.1) (Wang et al., 2005). High ratio of $\mathrm{C}_{1} / \mathrm{C}_{2}$ in the aerosols of Mt. Tai indicates that secondary sources are important for the formation of organic acids over the Mt. Tai. Daytime maxima of formic and acetic acids in particle phase (Figure 3) also indicate a secondary source for formic and acetic acids.

Kawamura et al. (2013) reported that oxalic acid is the most abundant dicarboxylic acid and largely emitted by the field burning of agricultural wastes in the NCP during the same campaign, but its major sources are photochemical processes (secondary sources). Concentrations of formic and acetic acids in particle phase show positive correlations with concentrations of oxalic acid $\left(\mathrm{C}_{1}: \mathrm{r}=0.63, \mathrm{C}_{2}: \mathrm{r}=0.54\right)$.

$\mathrm{CO}$ is an excellent tracer of primary combustion product. To evaluate the primary and secondary sources of formic and acetic acids during the MFB and LFB periods, we examined the relationship between formic acid or acetic acid and $\mathrm{CO}$ as shown in Figure 8. Concentrations of particulate acetic acid in daytime were found to increase linearly with $\mathrm{CO}$ during the MFB $(r=0.70)$ and LFB $(r=0.44)$ periods. Concentrations of gaseous acetic acid also showed a positive correlation with CO (MFB: $r=0.62$, LFB: $r=0.49)$. Concentrations of 
particulate formic acid were found to increase linearly with CO during the MFB $(r=0.64)$. However, concentrations of gaseous formic acid during the MFB and LFB periods and particulate formic acid during the LFB period did not correlate with CO $(\mathrm{r}<0.39)$. These correlation analyses suggest that emissions of acetic acid in both particle and gas phases over Mt. Tai are enhanced with an increase in the intensity of biomass burning during the MFB periods.

In addition, the slopes of regression lines drawn for acetic acid in gas- and particle-phases and CO are different between the MFB and LBF periods. In particle-phase, higher ratio of acetic acid/CO (0.003) was obtained during the MFB period, whereas lower ratio (0.001) was obtained during the LFB period. In gas-phase, higher ratio of acetic acid/CO (0.006) was obtained during the MFB period, whereas lower ratio (0.001) was obtained during the LFB period. $\mathrm{K}^{+}$as a biomass tracer shows a significant correlation with $\mathrm{CO}$, whereas the slopes of the regression lines for $\mathrm{K}^{+}$and $\mathrm{CO}$ are different between the MFB and LFB periods (Figure A5). Ratio of $\mathrm{K}^{+} / \mathrm{CO}(0.007)$ obtained from the slope of $\mathrm{K}^{+}$and $\mathrm{CO}$ during the MFB period was lower than that during the LFB period (0.001). $\mathrm{SO}_{4}{ }^{2-}$ as a fossil fuel combustion and industrial emission tracer shows a significant correlation with $\mathrm{CO}$, whereas the slopes of the regression lines for $\mathrm{SO}_{4}{ }^{2-}$ and $\mathrm{CO}$ are different between the MFB and LFB periods (Figure A6). Ratio of $\mathrm{SO}_{4}{ }^{2-} / \mathrm{CO}(0.112)$ obtained from the slope of $\mathrm{SO}_{4}{ }^{2-}$ and CO during the MFB period was lower than that during the LFB period (0.056). The higher ratios of $\mathrm{K}^{+} / \mathrm{CO}$ during the MFB period indicate a strong influence of field burning of agricultural wastes in the NCP. The lower ratios of $\mathrm{K}^{+} / \mathrm{CO}$ during the LFB period suggest an influence of contribution of $\mathrm{CO}$ from other sources such as fossil fuel combustion in the surroundings of North China. These results again suggest that abundant gas- and particle-phase acetic acid is directly emitted from the field burning of agricultural wastes.

During the campaign, ethane, ethene, propane, and propene (highly volatile hydrocarbons) are emitted from open burning of crop residue in the NCP (Kanaya et al., 
2009), which are important precursors of acetic acid (Warneck, 2005). Concentrations of these hydrocarbons were reported to increase under the influence of biomass burning plumes in the NCP (Kanaya et al., 2009). The daytime peaks of particulate and gaseous acetic acid can be explained by secondary processing via photochemical oxidation of volatile hydrocarbons over Mt. Tai. We plotted the ratios of acetic acid in total monocarboxylic acids $\left(\mathrm{C}_{2} /\right.$ total MCA) against $\mathrm{K}^{+}$(Figure 9). Ratios of $\mathrm{C}_{2}$ to total MCA in both gas- and particle-phases increased with an increase in CO concentrations during the MFB and LBF periods. In particular, contributions of $\mathrm{C}_{2}$ to total MCA during the MFB period showed a significant correlation with CO (gas: $r=0.93$, particle: $r=0.80$ ). These positive correlations suggest that acetic acid is selectively produced in the atmosphere by the photochemical oxidation of volatile hydrocarbons when organic precursors are transported over the summit of Mt. Tai from the field burning areas in lowland. We consider that primary emission and secondary formation of gas- and particle-phase acetic acid are associated with field burning of agricultural wastes in the NCP.

\subsection{High abundances of biogenic monocarboxylic acids}

Lactic acid is produced by lactobacillus (Cabredo et al., 2009), which is known to exist in soil (Huysman and Verstraete, 1993) and emitted from plant tissues in agricultural farm (primary origin) (Raja et al., 2008). This organic acid can also be produced by the oxidation of isoprene with ozone (Nguyen et al., 2010) (secondary origin). Gaseous and particulate lactic acid did not correlate $(\mathrm{r}<-0.15)$ with 2-methyltetrols, good tracers of isoprene-derived secondary organic aerosols (Fu et al., 2012). Isopentanoic acid can be produced by bacteria such as Bacteroides ruminicola and Megasphaera elsdenii (Allison, 1978). We found a strong positive correlation between lactic and isopentanoic acids in both gas $(r=0.91)$ and particle $(r=0.93)$ phases (Figure 10). This result is similar to that obtained for snow pit samples from high mountain site in central Japan, although the snow samples are 
490 influenced by the outflow of Asian dust (Mochizuki et al., 2016). We suggest that major 491 portion of lactic and isopentanoic acids were directly derived from the terrestrial ecosystem. 492 Microbial productivity involved with lactic and isopentanoic acids should widely exist in the terrestrial ecosystems in China. Hence, we conclude that these LMW monoacids are mainly derived from microbial sources.

Average particle phase concentration of lactic acid $\left(789 \mathrm{ng} \mathrm{m}^{-3}\right)$ is one order of

\section{Summary and conclusions}

Gaseous (G) and particulate (P) low molecular weight (LMW) monocarboxylic acids, including normal $\left(\mathrm{C}_{1}-\mathrm{C}_{10}\right)$, branched $\left(\mathrm{iC}_{4}-\mathrm{iC}_{6}\right)$, hydroxyl (lactic and glycolic), and aromatic (benzoic) structures, were detected in the ambient air samples collected at the summit of Mt. Tai in the North China Plain (NCP). We found that acetic acid was the most abundant 
gaseous species whereas formic acid was the most abundant particulate species. Significantly high concentrations of formic (average, G: $1570 \mathrm{ng} \mathrm{m}^{-3}, \mathrm{P}: 1410 \mathrm{ng} \mathrm{m}^{-3}$ ) and acetic (G: 3960 $\mathrm{ng} \mathrm{\textrm {m } ^ { - 3 }}, \mathrm{P}: 1120 \mathrm{ng} \mathrm{m}^{-3}$ ) acids were detected during the period of inflow of air plumes from the field burning of agricultural waste (wheat straw) in the NCP. Because gas- and particle-phase concentrations of formic and acetic acids in daytime are correlated $(\mathrm{r}=0.32$ 0.64) with $\mathrm{K}^{+}$(a field burning tracer), field burning of agricultural waste should be an important primary source of LMW monoacids over Mt. Tai. In addition, we found a large fraction $\left(F_{\mathrm{p}}\right)$ of particulate formic $(0.49)$ and acetic $(0.32)$ acids in the total $(\mathrm{G}+\mathrm{P})$ concentrations. We suggest that primary emission and secondary formation of gaseous and particulate acetic acid are associated with field burning of agricultural waste in the NCP. We also found high concentrations of isopentanoic acid (331 $\left.\mathrm{ng} \mathrm{m}^{-3}\right)$ and lactic acid $\left(917 \mathrm{ng} \mathrm{m}^{-3}\right)$ in particle phase, suggesting that biological sources are also important for LMW monoacids in organic aerosols. LMW monoacids emitted from the field burning of agricultural wastes importantly contribute to the formation of organic aerosols in Central East China.

\section{Acknowledgements}

This study was in part supported by the Japanese Ministry of Education, Culture, Sports, Science and Technology (MEXT) through grant-in-aid Nos. 17340166, 1920405 and 24221001. We also acknowledge the financial support by the Global Environment Research Fund (B-051) of the Ministry of the Environment, Japan, for the shipping of the instruments to Mt. Tai. We thank K. Okuzawa and S. G. Aggarwal for their supports during sample collection. We also thank Dr. Pakpong Pochanart for the collection of CO data. The data of this paper are available upon request to K. Kawamura (kkawamura@isc.chubu.ac.jp).

\section{References}


Alexander, J.M., Grassian, V.H., Young, M.A., Kleiber, P.D., 2015. Optical properties of selected components of mineral dust aerosol processed with organic acids and humic material. J. Geophys. Res. Atmos. 120, 2437-2452, doi:10.1002/2014JD022782.

Allison, M.J., 1978. Production of branched-chain volatile fatty-acids by certain anaerobic bacteria. Appl. Environ. Microbiol. 35, 872-877.

Andreae, M.O., 1983. Soot carbon and excess fine potassium: long-range transport of combustion-derived aerosols. Science 10, 1148-1151.

Andreae, M.O., Talbot, R.W., Andreae, T.W., Harris, R.C., 1988. Formic and acetic acid over the central Amazon region, Brazil. 1. Dry season. J. Geophys. Res. 93, 1616-1624.

Asensio, D., Peñuelas, J., Prieto, P., Estiarte, M., Filella, I., Llusià, J., 2008. Interannual and seasonal changes in the soil exchange rates of monoterpenes and other VOCs in a Mediterranean shrubland. Eur. J. Soil Sci. 59, 878-891.

Barsanti, K.C., McMurry, P.H., Smith, J.N., 2009. The potential contribution of organic salts to new particle growth. Atmos. Chem. Phys. 9, 2949-2957.

Brégonzio-Rozier, L., Siekmann, F., Giorio, C., Pangui, E., Morales, S.B., Temime-Roussel, B., Gratien, A., Michoud, V., Ravier, S., Cazaunau, M., Tapparo, A., Monod, A., Doussin, J.-F., 2015. Gaseous products and secondary organic aerosol formation during long term oxidation of isoprene and methacrolein. Atmos. Chem. Phys. 15, 2953-2968, doi:10.5194/acp-15-2953-2015.

Cabredo, S., Parra, A., Saenz, C., Anzano, J., 2009. Bioaerosols chemometric characterization by laser-induced fluorescence: air sample analysis. Talanta 77, $1837-1842$.

Cape, J.N., Cornell, S.E., Jickells, T.D., Nemitz, E., 2011. Organic nitrogen in the atmosphere - Where does it come from? A review of sources and methods. Atmos. Res. 102, 30-48, doi:10.1016/j.atmosres.2011.07.009. 
Chebbi, A., Carlier, P., 1996. Carboxylic acids in the troposphere, occurrence, sources, and sinks: A review. Atmos. Environ. 30(24), 4233-4249.

Dibb, J.E., Arsenault, M., 2002. Shouldn't snowpacks be sources of monocarboxylic acids? Atmos. Environ. 36, 2513-2522.

Fu, P.Q., Kawamura, K., Okuzawa, K., Aggarwal, S.G., Wang, G., Kanaya, Y., Wang, Z., 2008. Organic molecular compositions and temporal variations of summertime mountain aerosols over Mt. Tai, North China Plain. J. Geophys. Res. 113, D19107, doi:10.1029/2008JD009900.

Fu, P.Q., Kawamura, K., Chen, J., Li, J., Sun, Y.L., Liu, Y., Tachibana, E., Aggarwal, S.G., Okuzawa, K., Tanimoto, H., Kanaya, Y., Wang, Z.F., 2012. Diurnal variations of organic molecular tracers and stable carbon isotope composition in atmospheric aerosols over Mt. Tai in the North China Plain: an influence of biomass burning. Atmos. Chem. Phys. 12, 8359-8375, doi:10.5194/acp-12-8359-2012.

Ge, X., Wexler, A.S., Clegg, S.L., 2011. Atmospheric amines - Part I. A review. Atmos. Environ. 45, 524-546.

Graham, B., Mayol-Bracero, O.L., Guyon, P., Roberts, G.C., Decesari, S., Facchini, M.C., Artaxo, P., Maenhaut, W., Köll, P., Andreae, M.O., 2002. Water-soluble organic compounds in biomass burning aerosols over Amazonia 1. Characterization by NMR and GC-MS. J. Geophys. Res. 107(D20), 8047, doi:10.1029/2001JD000336.

Huysman, F., Verstraete, W., 1993. Water-facilitated transport of bacteria in unsaturated soil columns: influence of cell surface hydrophobicity and soil properties. Soil Biol. Biochem. 25(1), 83-90.

Kanaya, Y., Pochanart, P., Liu, Y., Li, J., Tanimoto, H., Kato, S., Suthawaree, J., Inomata, S., Taketani, F., Okuzawa, K., Kawamura, K., Akimoto, H., Wang, Z.F., 2009. Rates and regimes of photochemical ozone production over Central East China in June 2006: a box 
model analysis using comprehensive measurements of ozone precursors. Atmos. Chem. Phys. 9, 7711-7723.

Kanaya, Y., Akimoto, H., Wang, Z.-F., Pochanart, P., Kawamura, K., Liu, Y., Li, J., Komazaki, Y., Irie, H., Pan, X.-L., Taketani, F., Yamaji, K., Tanimoto, H., Inomata, S., Kato, S., Suthawaree, J., Okuzawa, K., Wang, G., Aggarwal, S.G., Fu, P.Q., Wang, Y., Zhuang, G., 2013. Overview of the Mt. Tai Experiments (MTX2006) in central East China in June 2006: studies of significant regional air pollution. Atmos. Chem. Phys. 13, $8265-8283$.

Kawamura, K., Kaplan, I.R., 1984. Capillary gas chromatography determination of volatile organic acids in rain and fog samples. Anal. Chem. 56, 1616-1620.

Kawamura, K., Ng, L.L., Kaplan, I.R., 1985. Determination of organic-acids $\left(\mathrm{C}_{1}-\mathrm{C}_{10}\right)$ in the atmosphere, motor exhausts, and engine oils. Environ. Sci. Technol. 19, 1082-1086.

Kawamura, K., Gagosian, R.B., 1987. Implications of $\omega$-oxocarboxylic acids in the remote marine atmosphere for photo-oxidation of unsaturated fatty acids. Nature 325, 330-332.

Kawamura, K., Steinberg, S., Kaplan, I.R., 1996. Concentrations of mono- and di-carboxylic acids and aldehydes in southern California wet precipitations: comparison of urban and non-urban samples and compositional changes during scavenging. Atmos. Environ. 30, $1035-1052$.

Kawamura, K., Steinberg, S., Kaplan, I.R., 2000. Homologous series of $\mathrm{C}_{1}-\mathrm{C}_{10}$ monocarboxylic acids and $\mathrm{C}_{1}-\mathrm{C}_{6}$ carbonyls in Los Angeles and motor vehicle exhausts. Atmos. Environ. 34, 4175-4191.

Kawamura, K., Steinberg, S., Ng, L., Kaplan, I.R., 2001. Wet deposition of low molecular weight mono- and di-carboxylic acids, aldehydes and inorganic species in Los Angeles. Atmos. Environ. 35, 3917-3926.

Kawamura, K., Matsumoto, K., Tachibana, E., Aoki, K., 2012. Low molecular weight $\left(\mathrm{C}_{1}-\mathrm{C}_{10}\right)$ monocarboxylic acids, dissolved organic carbon and major inorganic ions in 
alpine snow pit sequence from a high mountain site, central Japan. Atmos. Environ. 62, 272-280.

Kawamura, K., Tachibana, E., Okuzawa, K., Aggarwal, S.G., Kanaya, Y., Wang, Z.F., 2013a. High abundances of water-soluble dicarboxylic acids, ketocarboxylic acids and $\alpha$-dicarbonyls in the mountaintop aerosols over the North China Plain during wheat burning season. Atmos. Chem. Phys. 13, 8285-8302, doi:10.5194/acp-13-8285-2013.

Kawamura, K., Okuzawa, K., Aggarwal, S.G., Irie, H., Kanaya, Y., Wang, Z., 2013 b. Determination of gaseous and particulate carbonyls (glycolaldehyde, hydroxyacetone, glyoxal, methylglyoxal, nonanal and decanal) in the atmosphere at Mt. Tai. Atmos. Chem. Phys. 13, 5369-5380, doi:10.5194/acp-13-5369-2013.

Keene, W.C., Galloway, J.N., Holden Jr., J.D., 1983. Measurement of weak organic acidity in precipitation from remote areas of the world. J. Geophys. Res. 88, 5122-5130.

Keene, W.C., Talbot, R.W., Andreae, M.O., Beecher, K., Berresheim, H., Castro, M., Farmer, J.C., Galloway, J.N., Hoffmann, M.R., Li, S.M., Maben, J.R., Munger, J.W., Norton, R.B., Pszenny, A.A.P., Puxbaum, H., Westberg, H., Winiwarter, W., 1989. An intercomparison of measurement systems for vapor and particulate phase concentrations of formic and acetic acids. J. Geophys. Res. 94, 6457-6471.

Kesselmeier, J., Staudt, M., 1999. Biogenic volatile organic compounds (VOC): An overview on emission, physiology, and ecology. J. Atmos. Chem. 33, 23-88.

Khan, J., Brimblecombe, P., Glegg, S.L., 1995. Solubilities of pyruvic acid and the lower $\left(\mathrm{C}_{1}-\mathrm{C}_{6}\right)$ carboxylic acids. Experimental determination of equilibrium vapour pressures above pure aqueous and salt solutions. J. Atmos. Chem. 22, 285-302.

Khwaja, H.A., 1995. Atmospheric concentrations of carboxylic acids and related compounds at a semiurban site. Atmos. Environ. 29, 127-139.

Kudo, S., Tanimoto, H., Inomata, S., Saito, S., Pan, X., Kanaya, Y., Taketani, F., Wang, Z., Chen, H., Dong, H., Zhang, M., Yamaji, K., 2014. Emissions of non-methane volatile 

organic compounds from open crop residue burning in the Yangtze River Delta region, China. J. Geophys. Res. Atmos. 119, 7684-7698, doi:10.1002/2013JD021044.

Legrand, M., Gros, V., Preunlert, S., Estève, R.S., Thierry, A.M., Pèpy, G., Jourdain, B., 2012. A reassessment of the budget of formic and acetic acids in the boundary layer at Dumont d'Urville (coastal Antarctica): The role of penguin emissions on the budget of several oxygenated volatile organic compounds. J. Geophys. Res. 117, D06308, doi:10.1029/2011JD017012.

Li, S.M., Winchester, J.W., 1989. Geochemistry of organic and inorganic ions of late winter arctic aerosols. Atmos. Environ. 33(11), 2401-2415.

Lim, H.J., Carlton, A.G., Turpin, B.J., 2005. Isoprene forms secondary organic aerosol through cloud processing: model simulations. Environ. Sci. Technol. 39, 4441-4446.

Liu, J., Zhang, Z., Parker, E.T., Veres, P.R., Toberts, J.M., de Gouw, J.A., Hayes, P.L., Jimenez, J.L., Murphy, J.G., Ellis, R.A., Huey, L.G., Weber R.J., 2012, On the gas-particle partitioning of soluble organic aerosol in two urban atmospheres with contrasting emissions: 2. Gas and particle phase formic acid. J. Geophys. Res. 117, D00V21.

Miyazaki, Y., Aggarwal, S.G., Singh, K., Gupta, P.K., Kawamura, K., 2009. Dicarboxylic acids and water-soluble organic carbon in aerosols in New Delhi, India, in winter: Characteristics and formation processes. J. Geophys. Res. 114, D19206, doi:10.1029/2009JD011790.

Miyazaki, Y., Sawano, M., Kawamura, K., 2014. Low-molecular-weight hydroxyacids in marine atmospheric aerosol: evidence of a marine microbial origin. Biogeosciences 11, 4407-4404.

Mochizuki, T., Kawamura, K., Aoki, K., Sugimoto, N., 2016. Long-range atmospheric transport of volatile monocarboxylic acids with Asian dust over high mountain snow site, central Japan. Atmos. Chem. Phys. 16, 14621-14633. 
Möhler, O., Benz, S., Saathoff, H., Schnaiter, M., Wanger, R., Schneider, J., Walter, S., Ebert, V., Wanger, S., 2008. The effect of organic coating on the heterogeneous ice nucleation efficiency of mineral dust aerosols. Environ. Res. Lett. 3(2).

Nguyen, T.B., Bateman, A.P., Bones, D.L., Nizkorodov, S.A., Laskin, J., Laskin, A., 2010. High-resolution mass spectrometry analysis of secondary organic aerosol generated by ozonolysis of isoprene. Atmos. Environ. 44, 1032-1042.

Paciga, A.L., Riipinen, I., Pandis, S.N., 2014. Effect of ammonia on the volatility of organic diacids. Environ. Sci. Technol. 48, 13769-13775.

Paulot, F., Wunch, D., Crounse, J.D., Toon, G.C., Millet, D.B., DeCarlo, P.F., Vigouroux, C., Deutscher, N.M., Abad, G.G., Notholt, J., Warneke, T., Hannigan, J.W., Warneke, C., de Gouw, J.A., Dunlea, E.J., De Maziere, M., Griffith, D.W.T., Bernath, P., Jimenez, J.L., Wennberg, P.O., 2011. Importance of secondary sources in the atmospheric budgets of formic and acetic acids. Atmos. Chem. Phys. 11, 1989-2013.

Pommier, M., Clerbaux, C., Coheur, P.F., Mahieu, E., Müller, J.F., Paton-Walsh, C., Stavrakou, T., Vigouroux, C., 2016. HCOOH distributions from IASI for 2008-2014: comparison with ground-based FTIR measurements and a global chemistry-transport model. Atmos. Chem. Phys. 16, 8963-8981.

Preunkert, S., Legrand, M., Jourdain, B., Dombrowski-Etchevers, I., 2007. Acidic gases $\left(\mathrm{HCOOH}, \mathrm{CH}_{3} \mathrm{COOH}, \mathrm{HNO}_{3}, \mathrm{HCl}\right.$, and $\left.\mathrm{SO}_{2}\right)$ and related aerosol species at a high mountain Alpine site (4360 m elevation) in Europe. J. Geophys. Res. 112, D23S12, doi:10.1029/2006JD008225.

Raja, S., Raghunathan, R., Yu, X.Y., Lee, T., Chen, J., Kommalapati, R.R., Murugesan, K., Shen, X., Qingzhong, Y., Valsaraj, K.T., Collett Jr., J.L., 2008. Fog chemistry in the Texas-Louisiana Gulf Coast corridor. Atmos. Environ. 42, 2048-2061. 
Rollins, A.W., Browne, E.C., Min, K.-E., Pusede, S.E., Wooldridge, P.J., Gentner, D.R., 694 Goldstein, A.H., Liu, S., Day, D.A., Russell, L.M., Cohen, R.C., 2012. Evidence for $\mathrm{NO}_{\mathrm{x}}$ control over nighttime SOA formation. Science 337 (6099), 1210-1212.

Simoneit, B.R.T., 2002. Biomass burning - a review of organic tracers for smoke from incomplete combustion. Appl. Geochem. 17, 129-162.

Stavrakou, T., Muller, J-F., Peeters, J., Razavi, A., Clarisse, L., Clerbaux, C., Coheur, P-F., Hurtmans, D., De Maziere, M., Vigouroux, C., Deutscher, N.M., Griffith, D.W.T., Jones, N., Paton-Walsh, C., 2012. Satellite evidence for a large source of formic acid from boreal and tropical forests. Nature Geoscience 5, 26-30.

Talbot, R.W., Beecher, K.M., Harriss, R.C., Cofer, W.R., 1988. Atmospheric geochemistry of formic and acetic-acids at a mid-latitude temperate site. J. Geophys. Res. Atmos. 93, $1638-1652$.

Tsai, Y.I., Kuo, S.C., 2013. Contributions of low molecular weight carboxylic acids to aerosols and wet deposition in a natural subtropical broad-leaved forest environment Atmos. Environ. 81, 270-279.

Wang, T., Cheung, T.F., Li, Y.S., Yu, X.M., Blake, D.R., 2002. Emission characteristics of $\mathrm{CO}, \mathrm{NO}_{\mathrm{x}}, \mathrm{SO}_{2}$ and indications of biomass burning observed at a rural site in eastern China. J. Geophys. Res. 107, 4157.

Wang, Y., Zhang, G., Tang, A., Yuan, H., Sun, Y., Chen, S., Zheng A., 2005. The ion chemistry and the source of PM2.5 aerosol in Beijing. Atmos. Environ. 39, 3771-3784.

Wang, Y., Zhuang, G., Zhang, X., Huang, K., Xu, C., Tang, A., Chen, J., An, Z., 2006. The ion chemistry, seasonal cycle, and sources of $\mathrm{PM}_{2.5}$ and TSP aerosol in Shanghai. Atmos. Environ. 40, 2935-2952.

Warneck, P., 2005. Multi-phase chemistry of $\mathrm{C}_{2}$ and $\mathrm{C}_{3}$ organic compounds in the marine atmosphere. J. Atmos. Chem. 51, 119-159. 
Yatavelli, R.L.N., Stark, H., Thompson, S.L., Kimmel, J.R., Cubison, M.J., Day, D.A., Campuzano-Jost, P., Palm, B.B., Hodzic, A., Thornton, J.A., Jayne, J.T., Eorsnop, D.R., Jimenez, J.L., 2014. Semicontinuous measurements of gas-particle partitioning of organic acids in a ponderosa pine forest using a MOVI-HRToF-CIMS. Atmos. Chem. Phys. 14, 1527-1546.

$\mathrm{Yu}$, S., 2000. Role of organic acids (formic, acetic, pyruvic and oxalic) in the formation of cloud condensation nuclei (CCN): a review. Atmos. Res. 53, 185-217.

Yuan, B., Veres, P.R., Warneke, C., Roberts, J.M., Gilman, J.B., Koss, A., Edwards, P.M., Graus, M., Kuster, W.C., Li, S.-M., Wild, R.J., Brown, S.S., Dubé, W.P., Lerner, B.M., Williams, E.J., Johnson, J.E., Quinn, P.K., Bates, T.S., Lefer, B., Hayes, P.L., Jimenez, J.L., Weber, R.J., Zamora, R., Ervens, B., Millet, D.B., Rappenglück, B., de Gouw, J.A., 2015. Investigation of secondary formation of formic acid: urban environment vs. oil and gas producing region. Atmos. Chem. Phys. 15, 1975-1993. 


\section{Figure captions}

Figure 1. A map of East Asia with the sampling site at Mt. Tai in the North China Plain.

Figure 2. Seven-day air mass back trajectories arriving at the summit of Mt. Tai (1534 m above sea level) at a level of $1500 \mathrm{~m}$ a. s. 1. with fir spots in Central East China for selected periods in June 2006.

Figure 3. Temporal variations in the concentrations of major monocarboxylic acids in gas and particle phases and $\mathrm{K}^{+}$. Open circles indicate gas phase samples and solid circles indicate particle phase samples. Shaded areas indicate nighttime.

Figure 4. Compositions of monocarboxylic acids in gas and particle phases during less field burning (LFB) and more field burning (LFB) influenced periods.

Figure 5. Temporal variations in particle phase fraction $\left(F_{\mathrm{p}}\right)$ for major organic acids. Shaded areas indicate nighttime.

Figure 6. Correlations of formic and acetic acids in gas and particle phases with levoglucosan in daytime during less field burning (LFB) and more field burning (LFB) influenced periods.

Figure 7. Correlations of formic and acetic acids in gas and particle phases with $\mathrm{K}^{+}$in daytime during less field burning (LFB) and more field burning (LFB) influenced periods.

Figure 8. Correlation plots of formic and acetic acids in gas and particle phases and carbon monoxide (CO) during less field burning (LFB) and more field burning (LFB) influenced periods.

Figure 9. Changes of contribution of particulate and gaseous acetic acid $\left(C_{2}\right)$ to total monocarboxylic acids (total MCA) in the Mt Tai during less field burning (LFB) and more field burning (LFB) influenced periods.

Figure 10. Correlation plots of lactic acid and isopentanoic acid in gas and particle phases. 


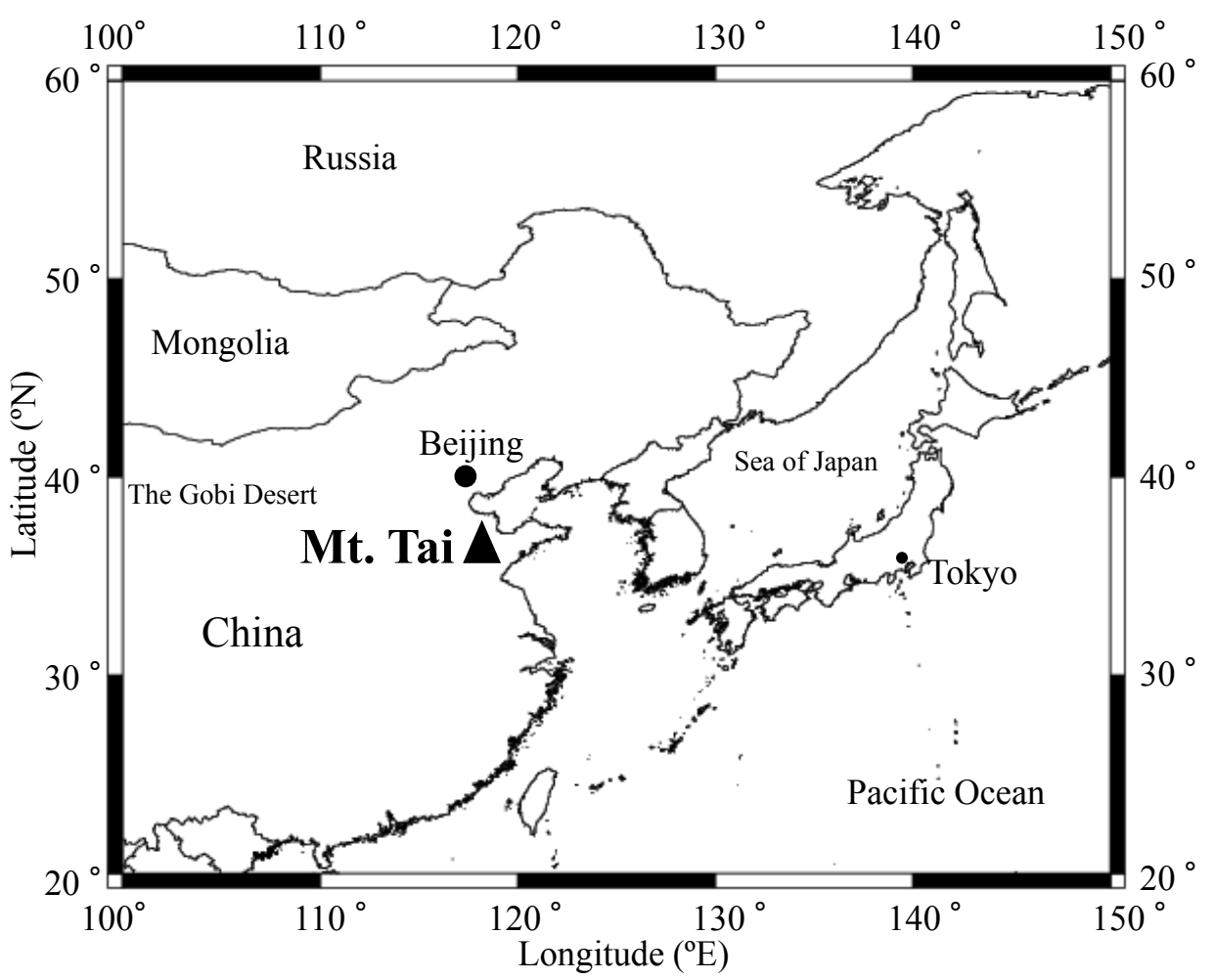

759 Figure 1. A map of East Asia with the sampling site at Mt. Tai in the North China Plain. 
(a) 2-4 June, 2006

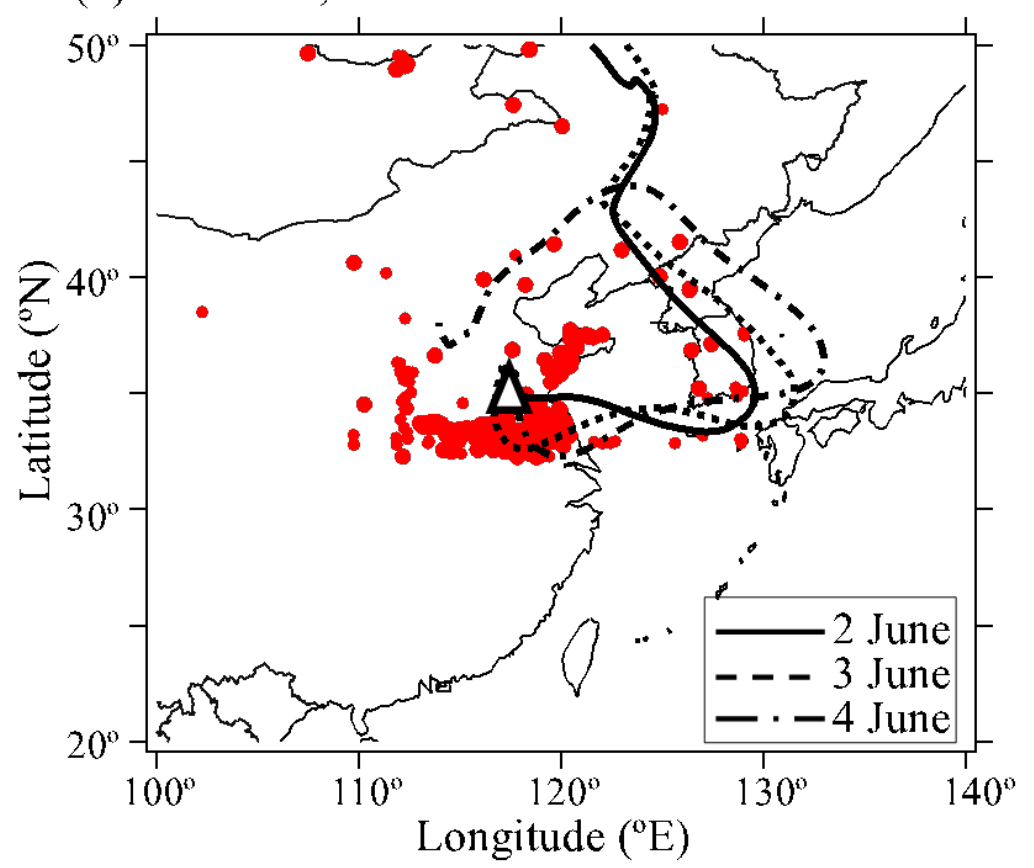

(b) 23-25 June, 2006

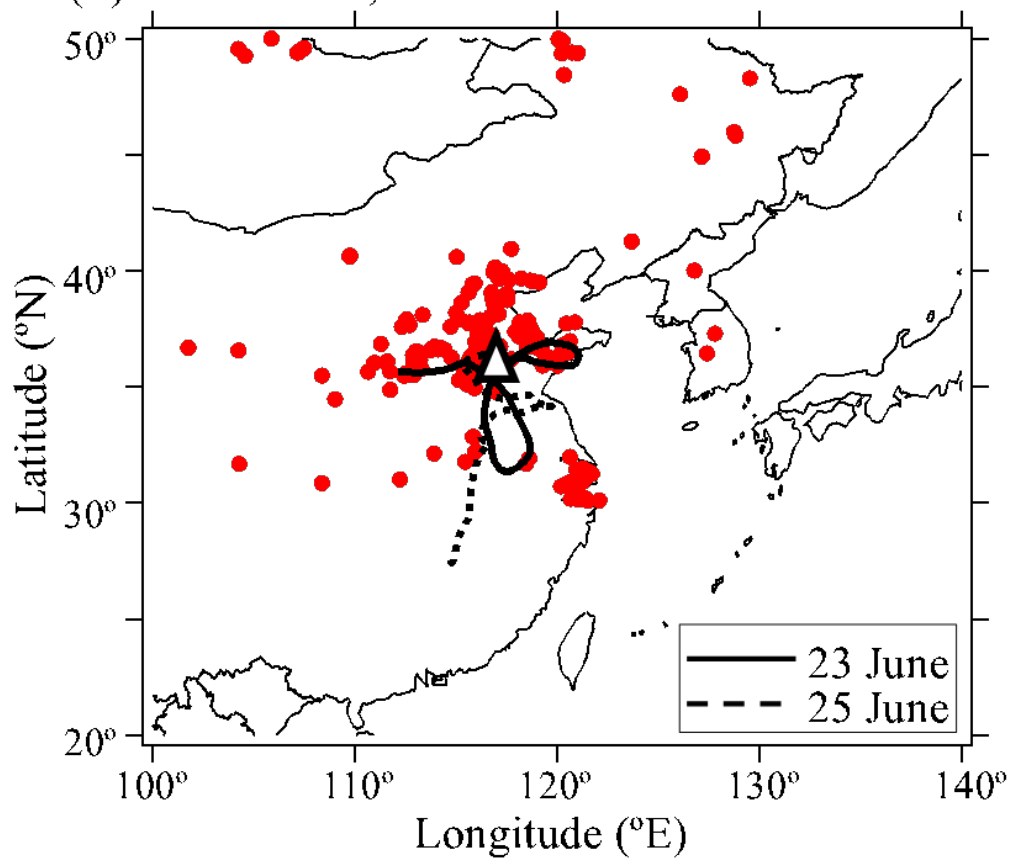

762 Figure 2. Seven-day air mass back trajectories arriving at the summit of Mt. Tai (1534 m

763 above sea level) at a level of $1500 \mathrm{~m}$ a. s. 1. with fire spots in Central East China for selected 764 periods in June 2006. 


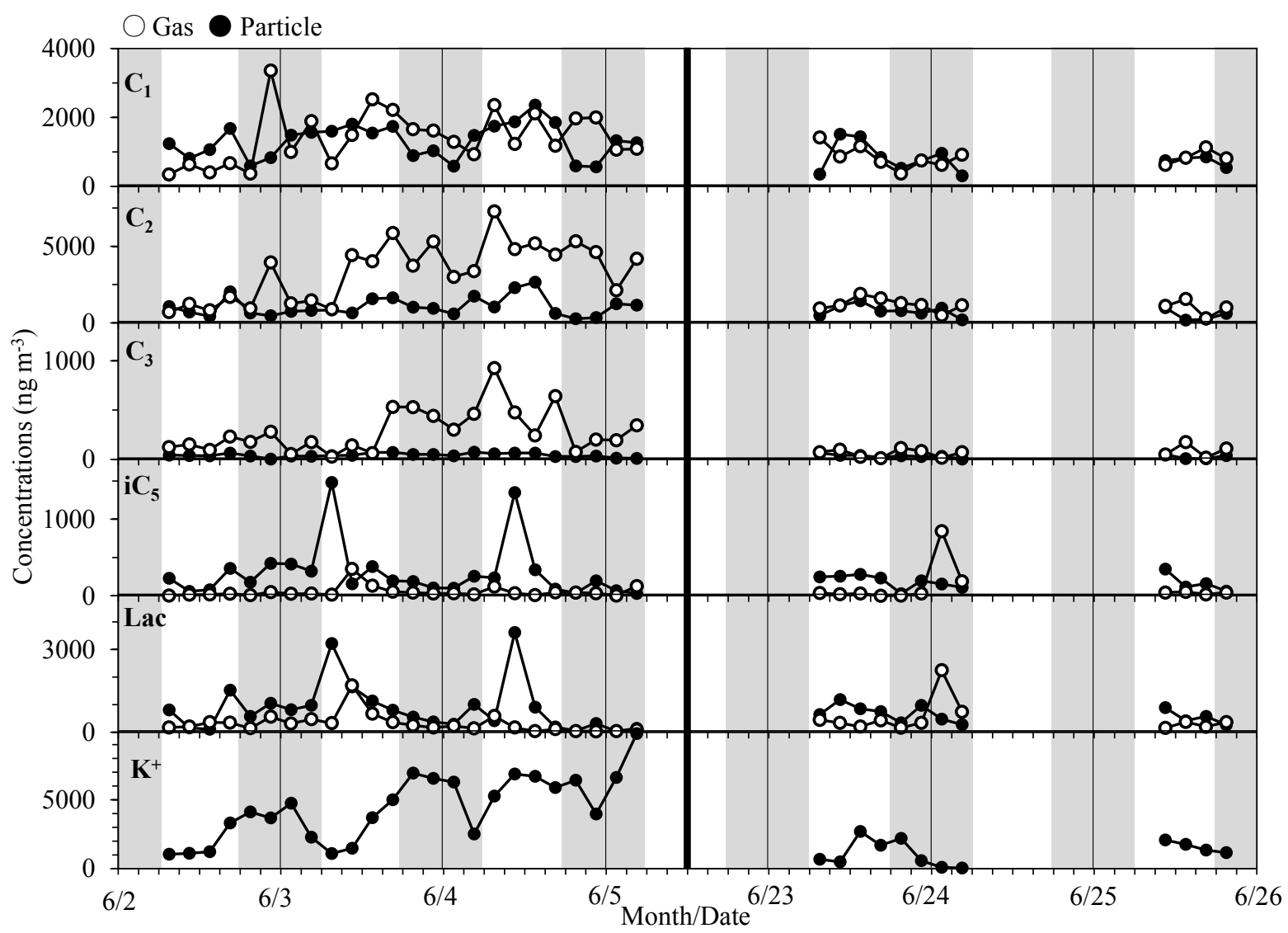

Figure 3. Temporal variations in the concentrations of major monocarboxylic acids in gas and particle phases and $\mathrm{K}^{+}$. Open circles indicate gas phase samples and solid circles indicate particle phase samples. Shaded areas indicate nighttime.

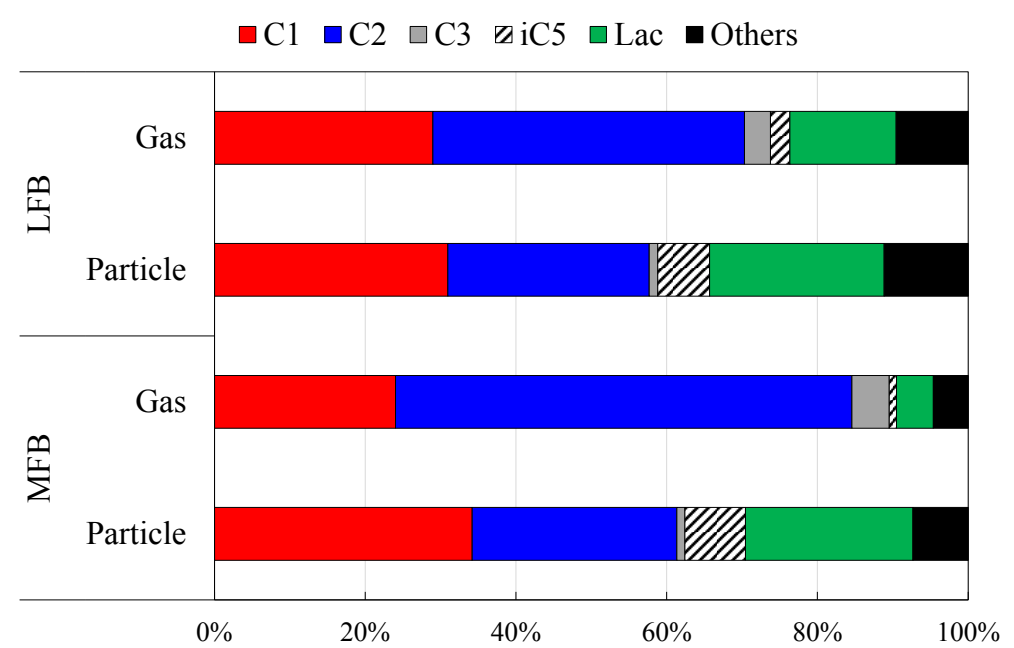

772 Figure 4. Compositions of monocarboxylic acids in gas and particle phases during less field

773 burning (LFB) and more field burning (LFB) influenced periods. 


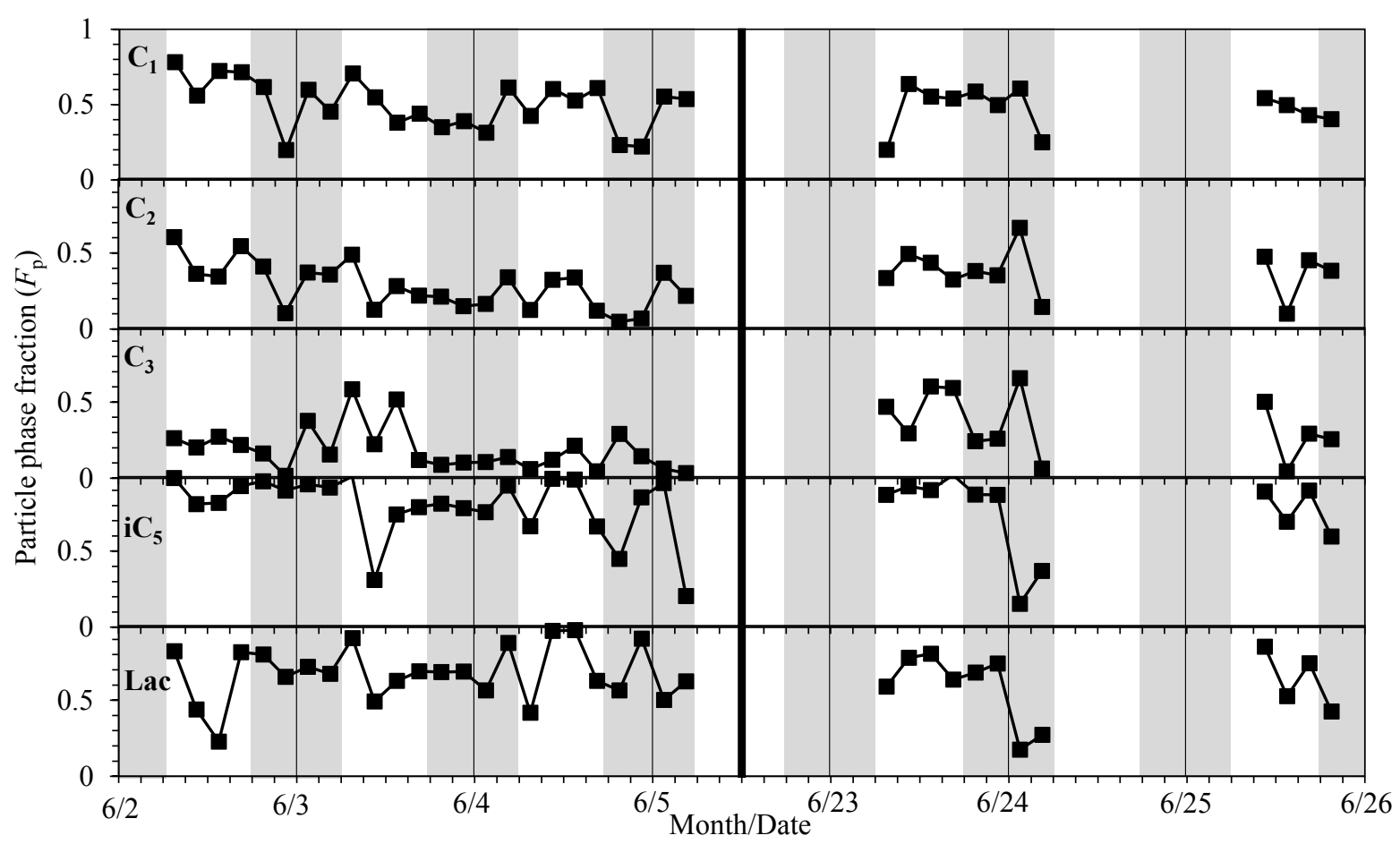

775 Figure 5. Temporal variations in particle phase fraction $\left(F_{\mathrm{p}}\right)$ for major organic acids. Shaded 776 areas indicate nighttime. 
778
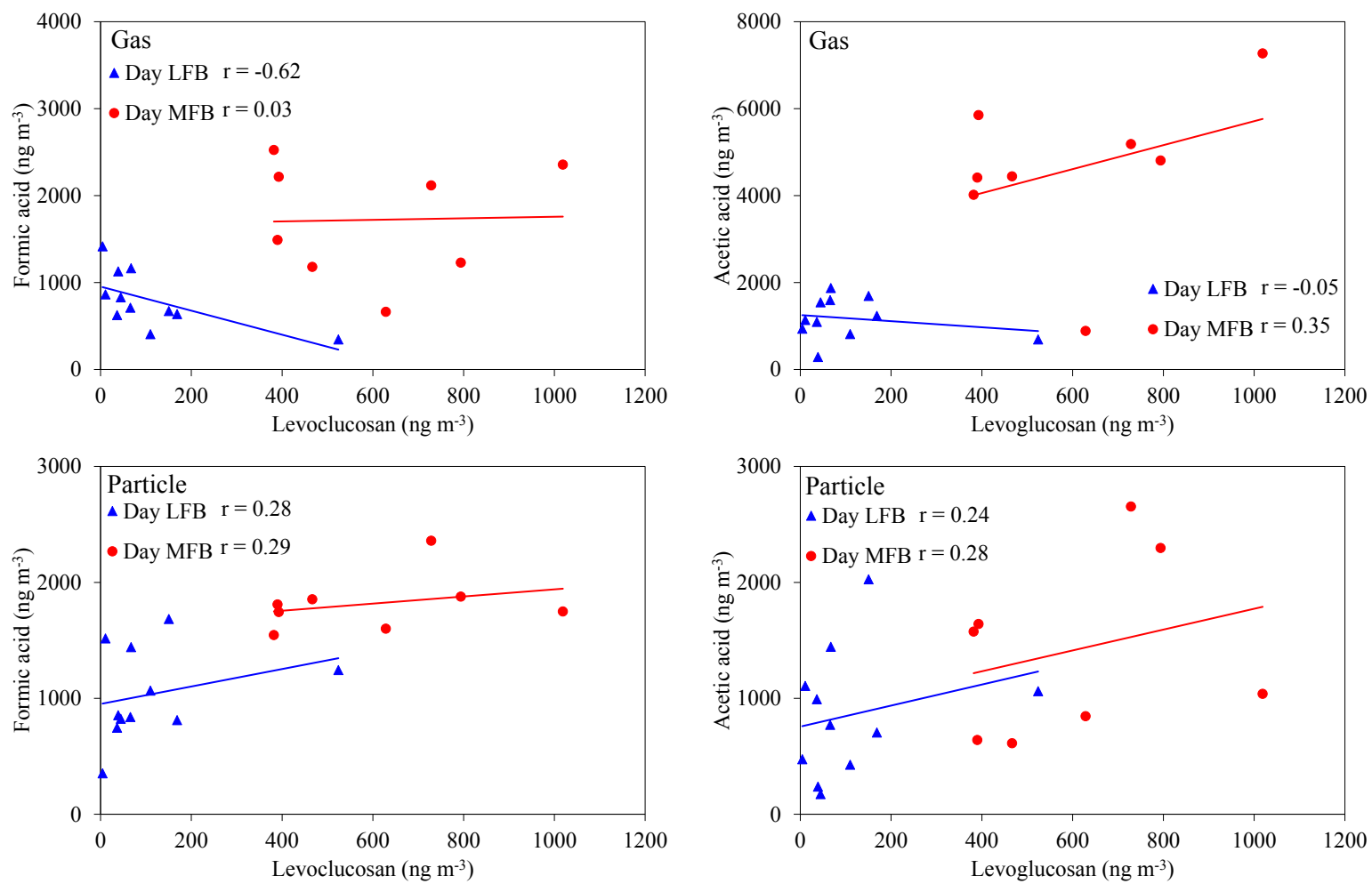

779

780 Figure 6. Correlations of formic and acetic acids in gas and particle phases with levoglucosan

781 in daytime during less field burning (LFB) and more field burning (LFB) influenced periods.

782
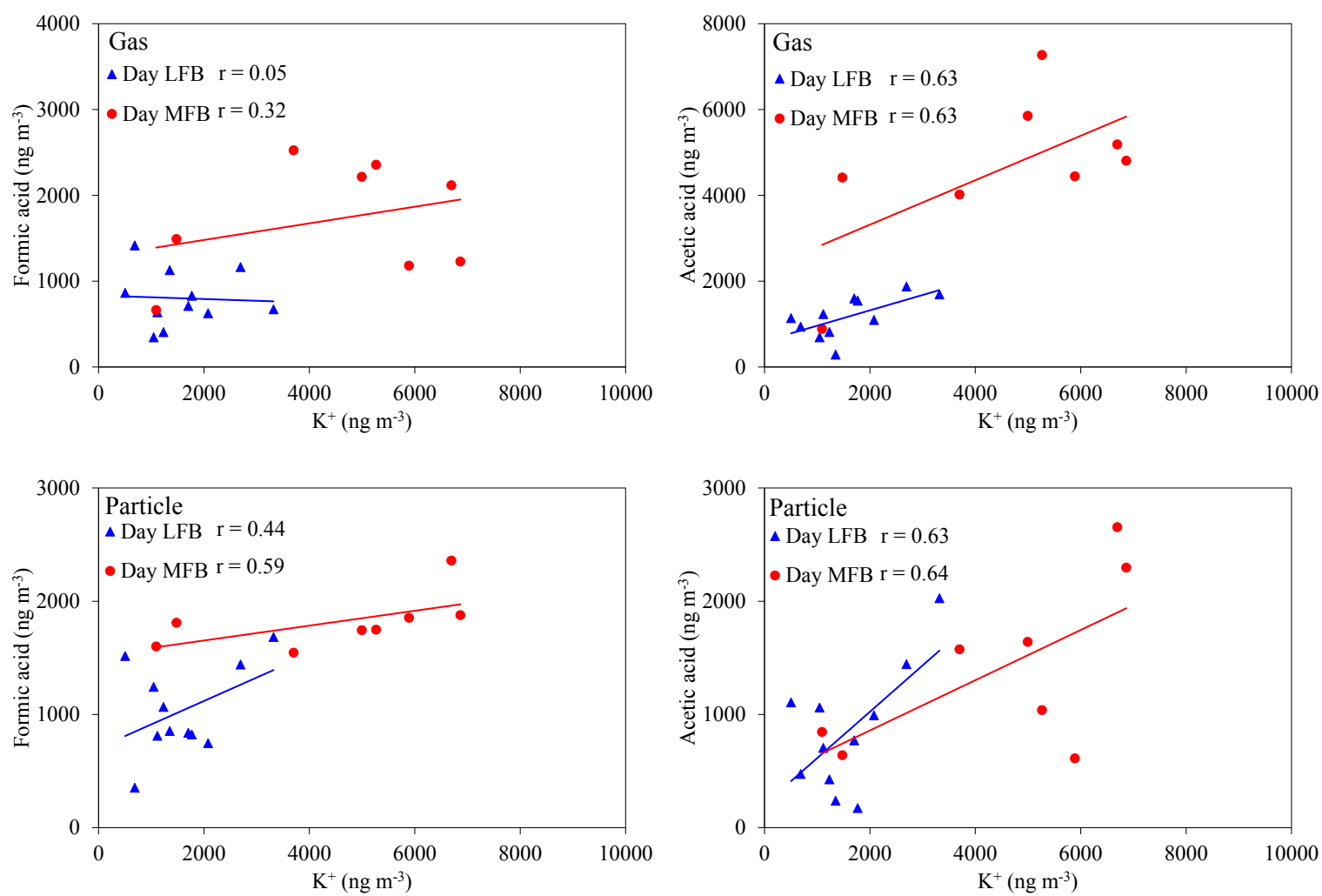

784 Figure 7. Correlations of formic and acetic acids in gas and particle phases with $\mathrm{K}^{+}$in

785 daytime during less field burning (LFB) and more field burning (LFB) influenced periods. 

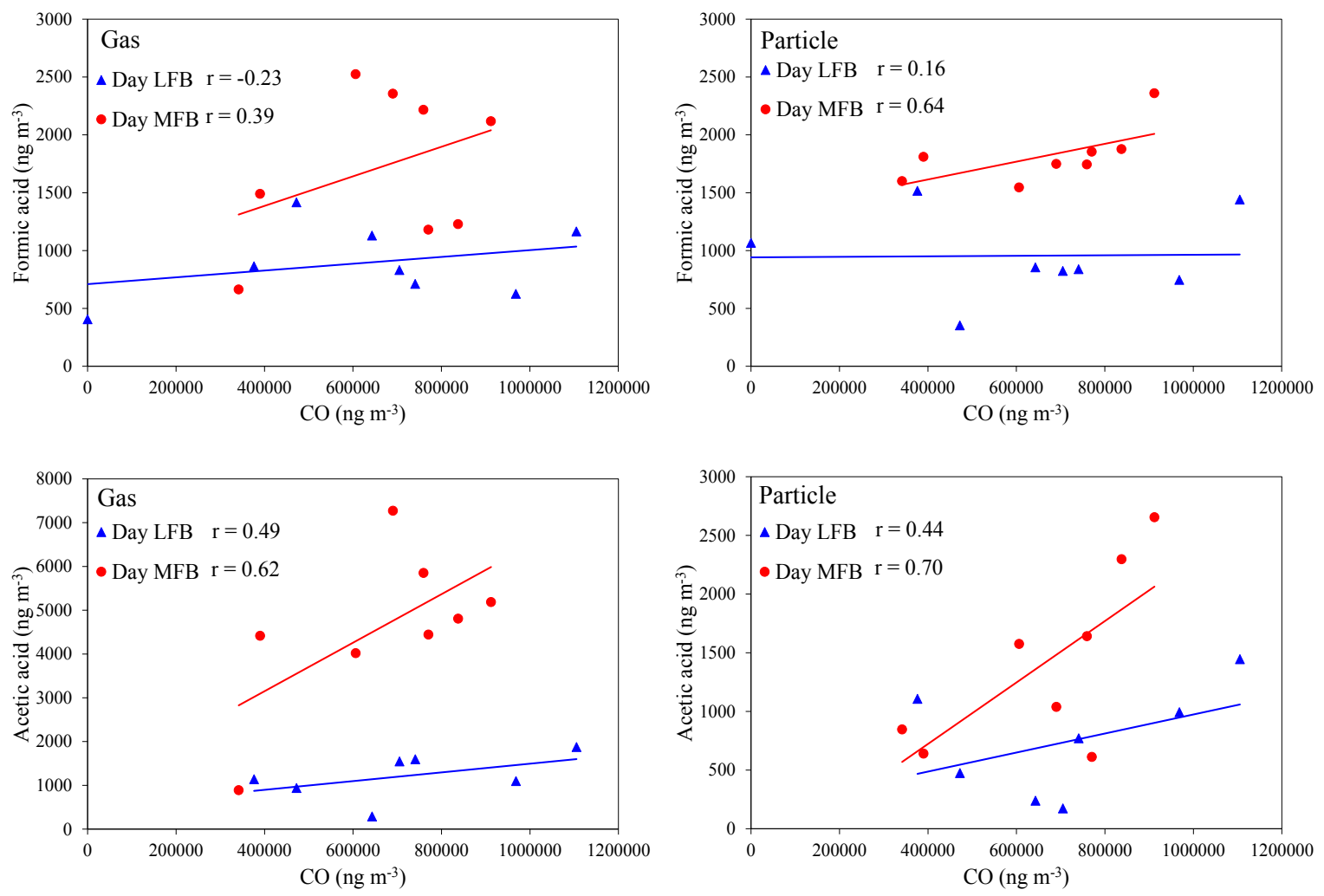

Figure 8. Correlation plots of formic and acetic acids in gas and particle phases and carbon

789 monoxide (CO) during less field burning (LFB) and more field burning (LFB) influenced 790 periods. 

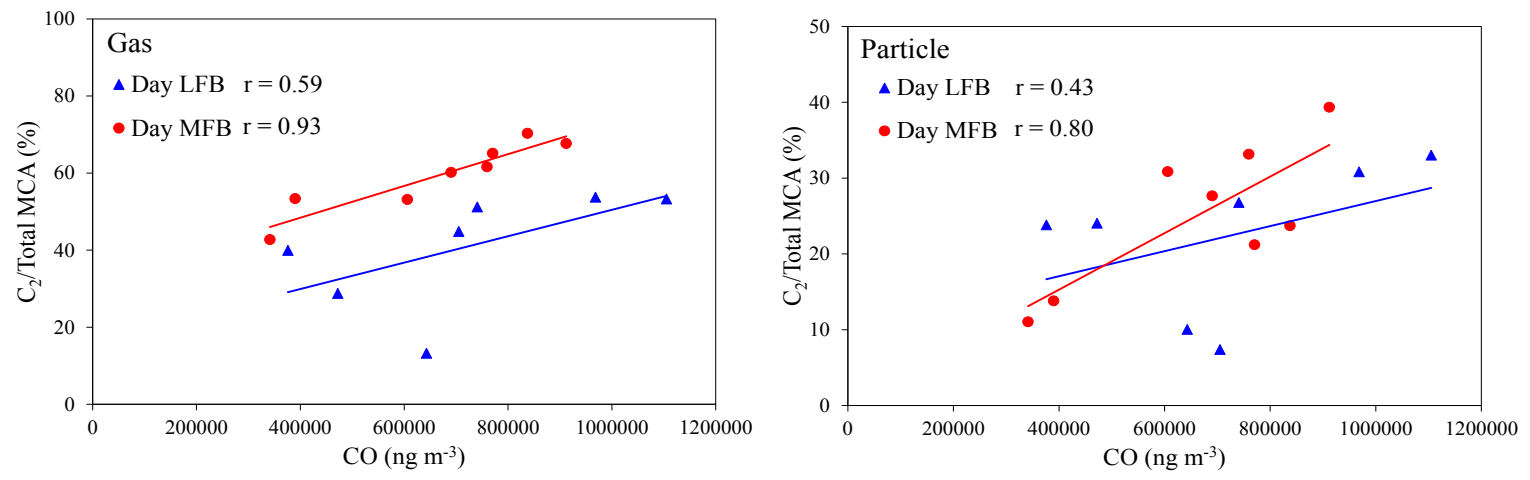

793 Figure 9. Changes of contribution of particulate and gaseous acetic acid $\left(\mathrm{C}_{2}\right)$ to total 794 monocarboxylic acids (total MCA) in the Mt Tai during less field burning (LFB) and more 795 field burning (LFB) influenced periods.

796

797

798

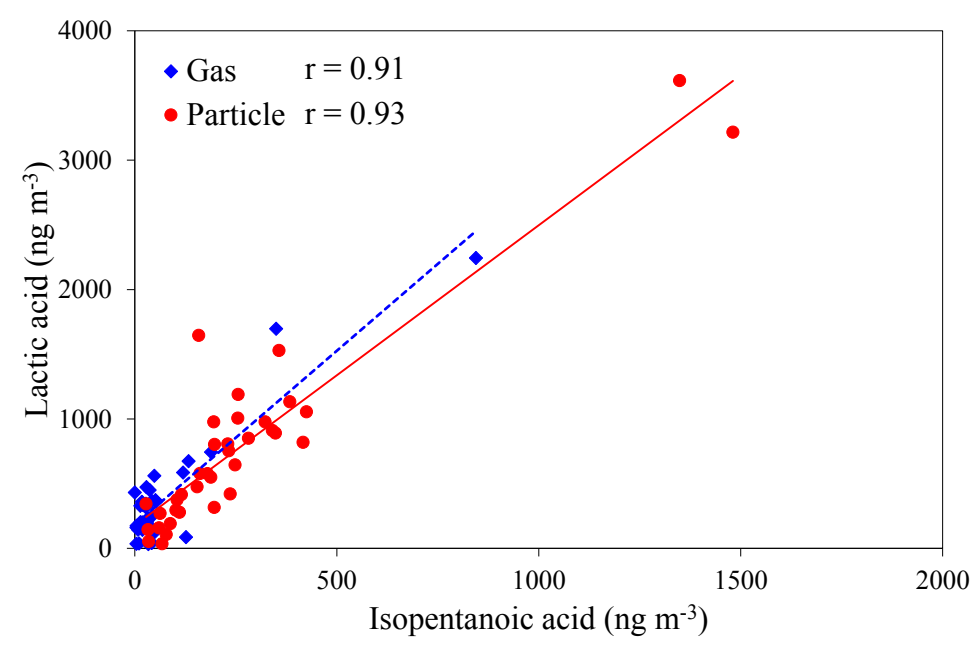

799 Figure 10. Correlation plots of lactic acid and isopentanoic acid in gas and particle phases. 
800 Table 1. Average concentrations $\left(\mathrm{ng} \mathrm{m}^{-3}\right)$ of gaseous and particulate low molecular weight

801 monocarboxylic acids and particle phase fraction $\left(F_{\mathrm{p}}\right)$ during less field burning (LFB) and

802 more field burning (MFB) influenced periods.

\begin{tabular}{|c|c|c|c|c|c|c|c|c|c|c|c|c|c|c|}
\hline \multirow{3}{*}{ Acid species } & \multicolumn{6}{|c|}{ MFB } & \multicolumn{6}{|c|}{ LFB } & \multirow{3}{*}{$\begin{array}{c}\text { MFB } \\
F_{\mathrm{p}} \\
\text { average }\end{array}$} & \multirow{3}{*}{$\begin{array}{c}\text { LFB } \\
F_{\mathrm{p}} \\
\text { average }\end{array}$} \\
\hline & \multicolumn{3}{|c|}{ Gas } & \multicolumn{3}{|c|}{ Particle } & \multicolumn{3}{|c|}{ Gas } & \multicolumn{3}{|c|}{ Particle } & & \\
\hline & $\min$. & $\max$. & average & $\min$. & $\max$. & average & $\min$. & $\max$ & average & $\min$. & $\max$ & average & & \\
\hline \multicolumn{15}{|l|}{ Aliphatic acids } \\
\hline Formic, $\mathrm{C}_{1}$ & 664 & 2520 & 1570 & 570 & 2360 & 1410 & 346 & 3360 & 890 & 307 & 1690 & 883 & 0.47 & 0.52 \\
\hline Acetic, $\mathrm{C}_{2}$ & 888 & 7270 & 3960 & 263 & 2650 & 1120 & 289 & 3940 & 1270 & 174 & 2030 & 763 & 0.24 & 0.38 \\
\hline Propionic, $\mathrm{C}_{3}$ & 28 & 927 & 324 & 12 & 74 & 45 & 12 & 280 & 106 & 4 & 65 & 33 & 0.19 & 0.30 \\
\hline Isobutyric, $\mathrm{iC}_{4}$ & 2 & 90 & 37 & 0 & 42 & 16 & 7 & 45 & 23 & 1 & 33 & 12 & 0.35 & 0.32 \\
\hline Butyric, $\mathrm{C}_{4}$ & 4 & 192 & 77 & 3 & 42 & 17 & 5 & 83 & 36 & 1 & 26 & 11 & 0.30 & 0.27 \\
\hline Isopentanoic, $\mathrm{iC}_{5}$ & 4 & 350 & 64 & 33 & 1480 & 331 & 0 & 844 & 79 & 28 & 425 & 196 & 0.76 & 0.80 \\
\hline Pentanoic, $\mathrm{C}_{5}$ & 0 & 12 & 4 & 0 & 8 & 2 & 0 & 9 & 2 & 0 & 11 & 3 & 0.46 & 0.58 \\
\hline Isohexanoic, $\mathrm{iC}_{6}$ & 0 & 8 & 2 & 0 & 4 & 2 & 0 & 4 & 0 & 0 & 5 & 2 & 0.62 & 0.92 \\
\hline Hexanoic, $\mathrm{C}_{6}$ & 0 & 31 & 4 & 2 & 17 & 9 & 0 & 30 & 5 & 0 & 17 & 5 & 0.78 & 0.61 \\
\hline Heptanoic, $\mathrm{C}_{7}$ & 0 & 5 & 2 & 0 & 10 & 2 & 0 & 5 & 2 & 1 & 7 & 2 & 0.48 & 0.50 \\
\hline Octanoic, $\mathrm{C}_{8}$ & 0 & 10 & 3 & 1 & 41 & 13 & 0 & 15 & 8 & 1 & 26 & 11 & 0.77 & 0.57 \\
\hline Nonanoic, $\mathrm{C}_{9}$ & 4 & 370 & 59 & 1 & 117 & 40 & 0 & 400 & 123 & 4 & 693 & 112 & 0.42 & 0.41 \\
\hline Decanoic, $\mathrm{C}_{10}$ & 0 & 9 & 2 & 0 & 18 & 5 & 0 & 9 & 3 & 0 & 20 & 4 & 0.59 & 0.36 \\
\hline Sub total & & & 6110 & & & 3010 & & & 2550 & & & 2040 & & \\
\hline \multicolumn{15}{|l|}{ Aromatic acid } \\
\hline Benzoic, Benz & 2 & 119 & 40 & 5 & 98 & 27 & 6 & 48 & 25 & 2 & 34 & 17 & 0.51 & 0.39 \\
\hline \multicolumn{15}{|l|}{ Hydroxyacids } \\
\hline Lactic, Lac & 33 & 1700 & 319 & 36 & 3615 & 917 & 144 & 2240 & 433 & 107 & 1530 & 661 & 0.69 & 0.61 \\
\hline Glycolic, Glyco & 12 & 343 & 72.1 & 14 & 348 & 168 & 16 & 125 & 65.1 & 25 & 431 & 140 & 0.71 & 0.65 \\
\hline Sub total & & & 391 & & & 1090 & & & 498 & & & 801 & & \\
\hline
\end{tabular}

804

805 Table 2. Comparisons of atmospheric concentrations of formic and acetic acids in the

806 atmosphere over Mt. Tai (this work) with those in previous studies from multiple sites in the

807 world.

\begin{tabular}{|c|c|c|c|c|}
\hline $\begin{array}{rr}\text { Location } \\
\end{array}$ & & Formic acid $\left(\mathrm{ng} \mathrm{m}^{-3}\right)$ & Acetic acid $\left(\mathrm{ng} \mathrm{m}^{-3}\right)$ & References \\
\hline Mt. Tai, China (wheat biomass burning) & G & 1570 & 3960 & This study \\
\hline Los Angeles (urban) & G & 860 & 1800 & Kawamura et al. (2000) \\
\hline California, Pasadena (urban) & G & 4000 & - & Yuan et al. (2015) \\
\hline Utah (oil and gas producing region) & G & 4700 & - & Yuan et al. (2015) \\
\hline Amazon (tropical forest) & G & 3400 & 5900 & Andreae et al. (1988) \\
\hline Yangtze River Delta region, China (biomass burning) & G & - & 5000 & Kudo et al. (2014) \\
\hline Greenland (mountain) & G & 1070 & 1070 & Dibb and Arsenault (2002) \\
\hline France (Alps) & G & 640 & 750 & Preunkert et al. (2007) \\
\hline Pacific Ocean & G & 55 & 122 & Miyazaki et al. (2014) \\
\hline Antarctica & $\mathrm{G}$ & 92 & 75 & Legrand et al. (2012) \\
\hline Mt. Tai, China (wheat biomass burning) & $\mathrm{P}$ & 1410 & 1120 & This study \\
\hline Los Angeles (urban) & $\mathrm{P}$ & 163 & 120 & Kawamura et al. (2000) \\
\hline Amazon (tropical forest) & $\mathrm{P}$ & 46 & 48 & Andreae et al. (1988) \\
\hline Pacific Ocean & $\mathrm{P}$ & 2 & 8 & Miyazaki et al. (2014) \\
\hline Taiwan (subtropical forest) & $\mathrm{P}$ & 30 & 312 & Tsai and Kuo (2013) \\
\hline Alaska & $\mathrm{P}$ & 244 & 744 & Li and Winchester (1989) \\
\hline Beiging, China (urban) & $\mathrm{P}$ & 370 & 350 & Wang et al. (2005) \\
\hline Shanghai, China (urban) & $\mathrm{P}$ & 80 & 150 & Wang et al. (2006) \\
\hline
\end{tabular}

809 G: gas-phase, P: particle-phase 